\title{
SHAPING THE CITY THROUGH FOOD: \\ THE HISTORIC FOODSCAPE OF LISBON AS CASE STUDY
}

\begin{abstract}
One can take cities as palimpsests where environmental, economic and social contexts combine into buildings, streets, public spaces. There is, however, another shaping force: food. Despite being absent from today's urban planning, historically food systems played a crucial role in shaping pre-industrial cities, defining foodscapes. Food systems have since undergone major transformations, entailing pressing issues that jeopardize sustainable development. European cities provide the perfect lab for new solutions and an historical approach to their foodscapes enables a more holistic knowledge that may contribute to designing more resilient cities.

This article focuses on the foodscape of Lisbon (Portugal) as case study, describing the evolution of the city's food production spaces, distribution routes and retail spaces, to early $20^{\text {th }}$ century and to our days. Contemporary strategies and their impact on Lisbon's foodscape are also highlighted, and, finally, a reflection on how food systems may be explored within urban design, towards more sustainable solutions.
\end{abstract}

Keywords: Foodscape, Urban Design, Food Systems, Lisbon (PT) 
SHAPING THE CITY THROUGH FOOD:

THE HISTORIC FOODSCAPE OF LISBON AS CASE STUDY

\author{
"The feeding of cities has been arguably the greatest force shaping \\ civilisation, and it still is. In order to understand cities properly, we need \\ to look at them through food."
}

(Steel, 2013: 10)

\title{
Introduction
}

One can take the city as the physical materialization of immaterial forces. A palimpsest where environmental constraints, economic shifts, social movements and cultural traditions combine into buildings, streets and roads, public and private spaces. The natural structure of a city opposes to its cultural dimension and ways of life, clearly printed into its architecture (Telles, 1997: 17), and urban form. Among these shaping forces there have been the urban food systems, which define different foodscapes.

For centuries, food systems were powerful urban shapers, underlying the cities' location, organization and size, besides defining internal land uses, routes, the location of public spaces, or building usages. In the last decades, however, food has been largely absent from urban planning and politically regarded as a rural issue, or simply invisible, due to the increasing distance granted by processing, refrigeration, transport systems and cheap energy (Pothukuchi \& Kaufman, 1999: 213).

Current food systems jeopardize sustainable development, carrying severe consequences for the environment, economy,, society and for the future of cities — , where progressively more of the world's population will inhabit: - 68\% in 2050 (UN-DESA, 2018) - while being fed by relatively less farmers. Cities entail specific challenges for food systems, but they may also possess an outstanding potential to provide new solutions, especially in Europe. Lisbon (Portugal) provides a particular, yet representative case study.

The aim of this on-going research is to characterize the transformation of Lisbon's foodscape(s), in order to set a knowledge baseline to support and to frame the city's future management and initiatives. Spaces devoted to food production, distribution and retailing will be described for the early $20^{\text {th }}$ and $21^{\text {st }}$ centuries, and some local initiatives to tackle pressing food issues will be highlighted. This case study may enhance how food played a role in designing the urban 
environment in the past, and how it might be used to assess and develop urban design solutions for a more sustainable and resilient future.

\section{Contributions of Urban Morphology and UNESCO to the study of foodscapes}

A food system encompasses all the activities necessary to supply an urban settlement with food, including:

"[...] all biological processes (or agrobiodiversity) as well as the physical infrastructure involved in feeding a population: growing, harvesting, processing, packaging, transporting, marketing, consumption, and disposal of food and food-related items. It also includes the inputs needed and outputs generated at each of these steps. A food system operates within and is influenced by social, political, economic and environmental contexts. It also requires human resources that provide labor, research and education. A food system is derived from and interacts with the ecosystem in which it is located." (FAO, 2011:15)

We can, therefore, infer that the concept encompasses ecosystems, infrastructures, labour, technology and the knowledge available, along with the inherent social, political, economic and environmental contexts, from which it evolves and on which it impacts. From food production, distribution, retailing, preparation and cooking to consumption and waste disposal, — to which food processing and packaging may be added — one may refer to urban food systems at any time and place in history, as diverse as their natural and cultural contexts. Although different food systems may coexist and overlap at a given time (local/global, organic/industrial, traditional), it is often possible to identify a dominant one.

These factors materialize into space, as each stage can be traditionally associated with a specific setting: food production with agricultural fields and pastures (later to greenhouses); food distribution with tracks, roads and streets; food retailing with markets, fairs and shops; and preparation and consumption primarily with domestic settings, besides restaurants. This research proposes the term foodscape to describe these materializations of the food systems into space. A foodscape can take on different scales, from global to local, urban to domestic. The city provides an especially rich set of these food spaces, combining different activities and scales. The concept may thus provide an operative tool for architects, urbanists, planners, landscape architects, etc., to engage with their surrounding environment. This study will privilege the stages related to food production, distribution and retailing, especially regarding fresh produce and meat.

This research about the evolution of Lisbon's foodscape (Portugal) was inspired by the understanding of the city as a palimpsest, and the methodology followed — designated as Historic 
Urban Foodscape - was specifically developed for this end, considering the methodological premises of the Schools of Urban Morphology and UNESCO's concept of Historic Urban Landscape (2011).

The study of the city through urban form - urban morphology — is an interdisciplinary research on which different scientific areas, several techniques and multiple sources of information converge and combine. Different Schools of Urban Morphology emerged since the first half of the $20^{\text {th }}$ century, according to the perspective and objectives adopted: English School (a descriptive and explanatory perspective), Italian School (prescriptive perspective, aiming for the definition of building typologies) and French School (evaluative perspective) (Moudon, 1997: 4$8)$.

These Schools of Urban Morphology share, however, consensual believes, such as that a city can be analysed through its physical form, divided into three basic elements - buildings, open spaces and streets - at multiple scales, and that historical understanding is key, since these elements are subjected to continuous transformations (Moudon, 1997: 7). Urban morphologists focus on the tangible result of social and economic forces and on how ideas and intentions are shaped into cities (Moudon, 1997: 3). Cartography is the primary source of information and it is used for synthesizing the remaining information collected, since it provides an objective record of the city at a specific moment (unlike descriptions and, under certain circumstances, statistics) — including information about buildings, roads, land use, property limits, topography, etc. It may be assessed by complementary statistics, bibliography, and photographs.

The argument proposed here is that among the urban shaping forces there are food systems, which define urban foodscapes. It is noticeable how each food activity may be respectively associated with the three elements of urban form: food production mainly with open spaces, distribution with roads and streets, and retailing activities with (super)market buildings.

Thus, the methodology developed stems from Urban Morphology both in the type of elements analysed and hierarchy of sources, being cartography also privileged, since the research's final aim is to map these food spaces. But it also stems from the concept of Historic Urban Landscape, developed by UNESCO to identify, assess, conserve and manage historic cities (2011: paragraph 10). This concept was developed as a strategy for sustainable development due to the current rapid urbanization processes, which might entail social and spatial deterioration (UNESCO, 2011: paragraphs 2, 3 and 5). The city is understood as the historical overlapping of different cultural and natural layers, including topography, geomorphology, hydrology and other natural features, built environment, infrastructures, open spaces and gardens, land use patterns, 
perceptions and visual relations and other intangible dimensions, such as social and cultural practices, economic processes, diversity and identity issues (UNESCO, 2011: paragraph 9). Its dynamic character is valued, promoting the sustainable use of urban spaces and social and functional diversity, "rooted in a balanced relationship [...] between the needs of present and future generations and the legacy of the past" (UNESCO, 2011: paragraph 11). This understanding of the city as a set of overlapping layers and the importance of characterizing a historic reality for future management were references for this research.

Combining both these views with the concept of food system, the Historic Urban Foodscape is understood as the successive overlapping of layers, including: geographical setting, urban form, food production spaces, food distribution routes and food retail spaces, which combine into a foodscape at any given moment. The spaces corresponding to these layers will be characterized, resorting to cartographic surveys, bibliography, photographs and statistics. Moreover, information collected through non-participant observation, but also as a volunteer (Refood) and during collaborations with other projects (Zero Desperdício, Fruta Feia) will be included.

This methodology allows the characterization of the dominant foodscape for both moments considered - early $20^{\text {th }}$ century and the contemporary reality — in a 'vertical' way, but also fosters 'horizontal' readings between each layer, evidencing their transformation over the last century. In addition, exploring cartography and digital systems (GIS and CAD) as means to gather and display information enables the spatialization of data that traditionally doesn't possess that dimension and the development of a map that can be progressively complemented by information, granting it a dynamic character. Finally, more than unveiling new information, studying the evolution of urban foodscapes is about building a new focus on the existing reality and sources, which may enhance a new understanding over the built environment and its management.

\section{Pre-industrial foodscapes: cities and their settings}

Despite being largely invisible in cities and urban planning nowadays, until quite recently food systems were key urban shaping factors. Since cities may be defined as "groups of populations that do not produce their own means of food subsistence" (Ascher, 2010: 21), the necessity of transporting food in, to feed these populations, is implied. However, for centuries, land transportation was difficult, hindering the movement of products and raw materials. Thus, the proximity to food resources was fundamental for the prosperity of a city, and towns were organized according to fertile soils, soft topographies, favourable climate and access to water: 
"Since soil can hardly be built, the general principle is to organize the entire community according to the best soils and, as far as possible, never occupy them with uses other than food production.” (Pereira dos Santos, 2010: 18)

This condition was highlighted by Vitruvius, in his Ten Books of Architecture (2006), quoting a dialogue between Alexander the Great and Dinocrates, the architect in charge of designing Alexandria. When confronted with the chosen site's inability to supply the city, the emperor condemned it by stating:

"Just as a new born child cannot feed himself or continue to grow into life without the milk of a nurse, so a city without fields or fruits that come from them into its walls cannot grow, since it cannot develop without the abundance of food, nor can it sustain its population if it has no resources." (Alexander, the Great, quoted by Vitruvius, 2006: 6970)

Cities, therefore, depended on local-based foodsheds, the geographical area from which a population obtains its food supply (Getz, 1989). First coined by Walter P. Hedden (1929: 17), the term was inspired by watersheds; but, while the main constraints to water flows are topographical, the configuration of a foodshed is shaped by economic, political and transportation structures. Thus, before the 1800's, foodsheds were predominantly local and crucial in determining the location of urban settlements (Blum-Evitts, 2009: iii).

Food supply was also important in terms of organizing the surrounding territories. In 1826, Johann Heinrich von Thünen described a model for the organization of a hinterland, based on an idealized model of a city centrally located in a fertile plain, free of topographical constraints, and where farmers made rational decisions to maximize profits (Björklund, 2010: 49). Under these conditions, the natural tendency would be that food production was organized in concentric rings around the city. The first ring held the production of more perishable fruits, vegetables and dairy products, being closer to the city and supporting higher rents, while benefiting from urban fertilizing waste (Steel, 2013: 69). The second ring was forested, supplying wood for construction, heating and cooking. The third ring consisted of grain fields that, although bulky, could be transported over longer distances. The last ring consisted of pastures, as cattle were able to walk to the city and could be slaughtered near the place of consumption. The area beyond these rings would be too distant to play a useful role in supplying the city (Steel, 2013: 71). Variations of this model could be found in several cities across Europe, such as Frankfurt-amMain, Worms, Basel, Munich (Braudel 1992), even London and Paris. 
Von Thünen included an important exception in his model: the presence of a navigable watercourse, which allowed products to travel faster. This variable was sufficient to alter its entire configuration, turning the production areas into parallel stripes along the watercourse (Steel, 2013: 71; Björklund, 2010: 51). Throughout most periods of history, rivers were, in fact, the only way a community could transcend its geography and many prosperous cities were founded on riverbanks, thus being able to obtain (food) resources from distant locations. Later on, railways (often described as 'man-made rivers') would play this role, promptly connecting fields and harbours, and allowing the transport of large amounts of cargo by land for the first time.

The difficult land transportation also limited the very size cities could attain, both in terms of population and area. A city's maximum population depended directly on the productive capacity of its surrounding soils and complementary food resources (mainly fisheries), and on its geographical situation, which enabled (or not) the access to other regions (Mumford, 1970: 316).

"These early cities [...] were still in essence agricultural towns: the main source of their food supply was in the land around them; [...] they could not grow beyond the limit of their local water supply and their local food sources." (Mumford, 1956)

Moreover, since food products could hardly travel for more than one day, the surrounding hinterland was limited to a radius of about 30 kilometres. Thus, there was a maximum size a town could attain before occupying its productive lands and reducing them to an insufficient area:

"The simple laws of geometry meant that the larger a city grew, the smaller the relative size of its rural hinterland became, until the latter could no longer feed the former." (Steel, 2013: 70-71)

Pre-industrial cities, therefore, were dependent on local food resources to establish their location, hinterland organization, maximum area and population. Cities held a relationship of proximity and interdependence with their local productive lands, strongly rooted in the territory and characterized by a circular metabolism of energy and matter between the urban and rural contexts. Food was also unequivocally present within the city, being crucial in shaping its urban form open spaces, streets and buildings. Food production spaces were close, almost interwoven with built spaces, and urban dwellers were in charge of their cultivation (Parham, 2015: 159-160; Björklund, 2010: 36-37; Mumford, 2004: 146-314). That productive land use was often preferential, with routes and buildings bypassing it, lasting even when the city expanded. The initial trails for food distribution would progressively become important axes of the city, turning into roads and streets often named after the (food) activities present along them. Squares that 
hosted weekly or monthly fairs, even when located outside the city walls, would later be incorporated into the city's fabric.

Vegetable gardens, livestock breeding, and food processing coexisted with housing and other urban activities in several cities (Parham, 2015: 47-52; Morris, 1995: 106-218; Braudel, 1992: 435). Specific buildings and spaces were designed to host food activities: barns and warehouses, markets, shops and restaurants. Attending food retail spaces was part of daily routine, being places of conviviality, tasting, exchange of knowledge.

"Roads were full of carts and wagons carrying vegetables and grain, rivers and docksides were packed with cargo ships and fishing boats, streets and back yards were full of cows, pigs and chickens.” (Steel, 2013: 6)

Pre-industrial food systems covered virtually every dimension of urban development. Not only did food supply influence urban form (land and building uses, layout of streets, squares and public spaces), but also contributed to determine the location, dimension and land organization around cities. Food enabled the interaction of different professions, social classes and communities, representing a strong link between populations, cities and territories. Food was part of the city.

\section{Globalized urban foodscapes: emancipation from the territory?}

With railways, industrialization and new food preserving techniques (canning and refrigeration), urban foodsheds expanded: food could be brought virtually from anywhere and local restrictions were no longer binding. While constraints became mainly economic, urban foodsheds covered the globe (Getz, 1989: 1). The ancestral urban connection with territory was disrupted, an emancipation previously impossible (Steel, 2013: 31-32). Cities expanded over their surrounding lands, annihilating the very conditions that had allowed them to thrive (Mumford, 1956).

Nowadays, food flows are ensured by complex air, sea, and land transport networks, with most food products travelling between 2500 and 4000 kilometres before reaching consumers (Vivas, 2011: 188). These increasing 'food miles' impact the environment $\left(\mathrm{CO}_{2}\right.$ emissions, energy consumption, reduction of biodiversity and ecosystem resilience), jeopardize social equality and reduce food quality (Paxton, 2011). Current industrialized food systems rely on a small number of distributors to ensure the only connection between numerous producers and consumers, a fragile link subject to strikes, economic disruptions, natural disasters and other external factors (Vivas, 2011: 186). This diminishes urban resilience and places cities in a situation of potential 
food insecurity, which might be exacerbated by climate change. Therefore, urban food systems face unprecedented challenges, as they seek to feed an increasing population while consuming fewer resources.

Besides, the perceived geographical emancipation is illusory. Even with technological innovations like hydroponics, humans still depend mostly on land for food $-90 \%$ of all calories in 2005 , according to Kastner et al. (2012: 6868). What we eat continues to impact our territory and cities, transforming traditional landscapes into new, standardized realities:

"When nowadays we stop eating cabbages cut as for the green broth soup, sautéed with olive oil, seasoned with garlic and a piece of cornbread, and we choose instead eating lettuce salads, we are changing the landscape we knew for one that results from hectares of intensive production greenhouses [...]" (Pereira dos Santos, 2010: 43)

In the last century, this profound transformation of foodscapes has gradually taken place all over the world, due to technological innovations, market systems and social transformations. On the other hand, the debate around sustainability and quality of life in the urban realm has intensified, as cities become denser and their consumption of natural resources increases, followed by large polluting outputs.

The development of more sustainable urban foodscapes — where both these realms merge — is therefore imperative, and urban design can help solving these challenges. Though cities pose specific challenges to food systems (urban expansion over productive lands, linear metabolisms, diet transition, populations who rely exclusively on trade to access food, etc.), they also hold exceptional potential, since it's here that most decisions regarding foodscapes are made, where creativity and resources combine, and where consumers concentrate.

European cities, especially, may provide the perfect lab, since their demographic pressure is less significant than in developing countries (UN-DESA, 2018); geographic and climatic conditions are fit for food production; financial and technological resources combine with awareness by stakeholders and consumers regarding food quality, environmental impact and healthy diets. Understanding their past might contribute to this exploration, by recalling previous land uses, food production potential, solutions fit for their specific geographical setting, culture and contexts that might be reused or re-designed to adjust contemporary conditions.

Lisbon (Portugal), in this context, is not an exception, but rather representative of these wider trends. Although it possesses specific natural, cultural and historical traits, several characteristics described for pre-industrial foodscapes were reflected into this city, and were concomitantly transformed, as urban food systems turned into globalized and industrialized systems, changing 
its corresponding foodscape. Thus, to study Lisbon's foodscape (described next) may enable parallel readings and dialogues with other cities that underwent similar processes, while contributing to a deeper knowledge about the city, which might be key in defining strategies for a more sustainable future.

\section{The Historic Urban Foodscape of Lisbon}

Geographical Setting: the ancestral basis

"In the singular situation of Lisbon lies its destiny."

(Brito, 1976: 16)

As described, the geographical setting was crucial for the foundation and prosperity of a city, and Lisbon reflects this. The city is located by the Tagus River estuary — one of the largest natural harbours in the Iberian Peninsula, along with Sado River - near the Atlantic Ocean and enclosed by mountain ridges to the North/Northeast and South (Brito, 1976: 11). Flat low lands spread along the riverbank, to the East and West, defining the largest area of flat fertile soils in Portugal (Telles, 1997: 38).

The nature of the soils was fundamental for the city's development and its local food supply over time. Particularly, the basaltic soils of today's Oeiras, to the West, which had an extraordinary potential for grain cultivation since Roman times (Telles, 1997: 38-39), and the fertile soils located further north, in the so-called 'Saloia Region'. Moreover, its placement by the river connected Lisbon to the rest of the country and the world, historically playing a fundamental role in the city's prosperity.

The natural topography provided hints to what would become the city's built-up area. The flatter areas next to watercourses and streams were cultivated for a long period of time. There are references to several streams within the city in place-names, such as Rio Seco ('dry river'), Alcântara ('the bridge'), Arroios ('small streams') or Valverde (roughly coincident with Avenida da Liberdade, flowing to the area of Terreiro do Paço, the city's main square). These valleys were the last areas to be occupied by buildings and infrastructures. With the hills, on the other hand, are associated important axes, notable buildings and monuments. Thus, topography was primordial in the occupation of Lisbon:

"The occupation of the site of Lisbon was strongly determined by its natural conditions, in particular by the characteristics of its relief. The coincidence of dominant relief lines and 
structuring lines of the urban fabric emphasizes their importance at the morphological level." (Telles 1997: 46)

The geographical setting was, thus, extremely important. However, when comparing the early$20^{\text {th }}$-century city with the current one, we find very distinct realities despite this common ancestral basis.

\section{The Foodscape of Lisbon in the early $20^{\text {th }}$ century}

Lisbon was depicted in the cartographic survey coordinated by Silva Pinto, from 1904-1911 (Fig. 1). It portrayed a city where it was still possible to find pre-industrial logics of territorial occupation. The built-up area was concentrated within the ring road, the military road roughly coincident with the ridgeline limiting Valverde's watershed (Pereira dos Santos, 2010: 52). Up until then, the city had grown mostly along the riverfront, due to the navigation activities, a situation that recalled von Thünen's territorial exception. From this moment on, railroads and tramways would allow the expansion towards inland, following two major routes to the North, coincident with structural valleys that are currently two main avenues: Avenida da Liberdade and Avenida Almirante Reis.

The city's food production spaces defined a productive belt around this built-up nucleus, composed of numerous farms ('quintas') and vegetable gardens, a memory that still lingers in place-names of several areas, such as Olivais ('olive groves') or Laranjeiras ('orange trees'), and street names. This production area further expanded northwards to the 'Saloia Region', a number of municipalities — Loures, Sintra, Mafra, among others - that are still part of the city's Metropolitan Area and food supply and possess exceptional features regarding soil fertility, orography, and weather (Paquete, 2001: 13-30). Soeiro de Brito emphasized their importance, by describing Loures's geographic depression as consisting of around a dozen horticultural nuclei, from which Loures itself stood out, providing about two thirds of the region's agricultural products (Brito, 1976: 167-168). This area supplied Lisbon with vegetables and fruits, grain, dairy cattle and sheep, both for meat and cheeses (Brito, 1976: 168), and was key in the definition of Lisbon's local foodshed, since its foundation. 


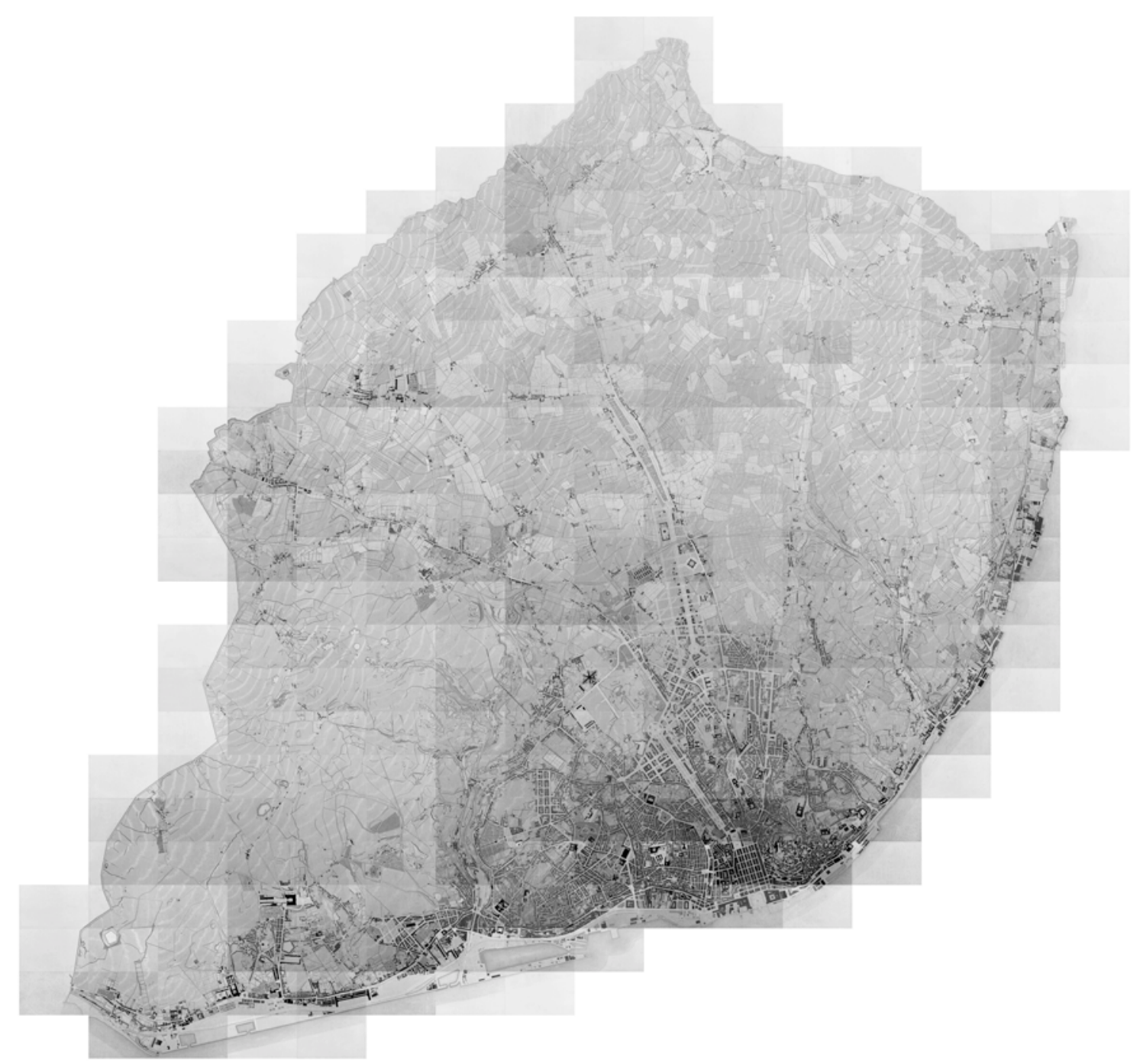

Figure 1: "Cartographic map by Silva Pinto 1904-1911 CC Câmara Municipal de Lisboa.”

However, other production spaces - closer to the urban settlement and today fully absorbed by the built fabric - also played an important role, such as Campo Grande (Fig. 2) and Campo Pequeno ('Big Field' and 'Little Field'), both with high grain yields; or the vegetable gardens along the valleys of Alcântara (Fig. 3) and Valverde, today Avenida da Liberdade (Pereira dos Santos, 2010: 48). In Valverde, people circulated peripherally, at the base of the slope, through the route connecting the streets of Portas de Santo Antáo, São José, Santa Marta and São Sebastião, which ultimately led to the 'Saloia Region' (Pereira dos Santos, 2010: 51). Some urban food production areas even attained higher yields than the 'Saloia Region': 500000 reis/ha compared to 360000 reis/ha, in 1887 (Pereira, 1915: 119). 


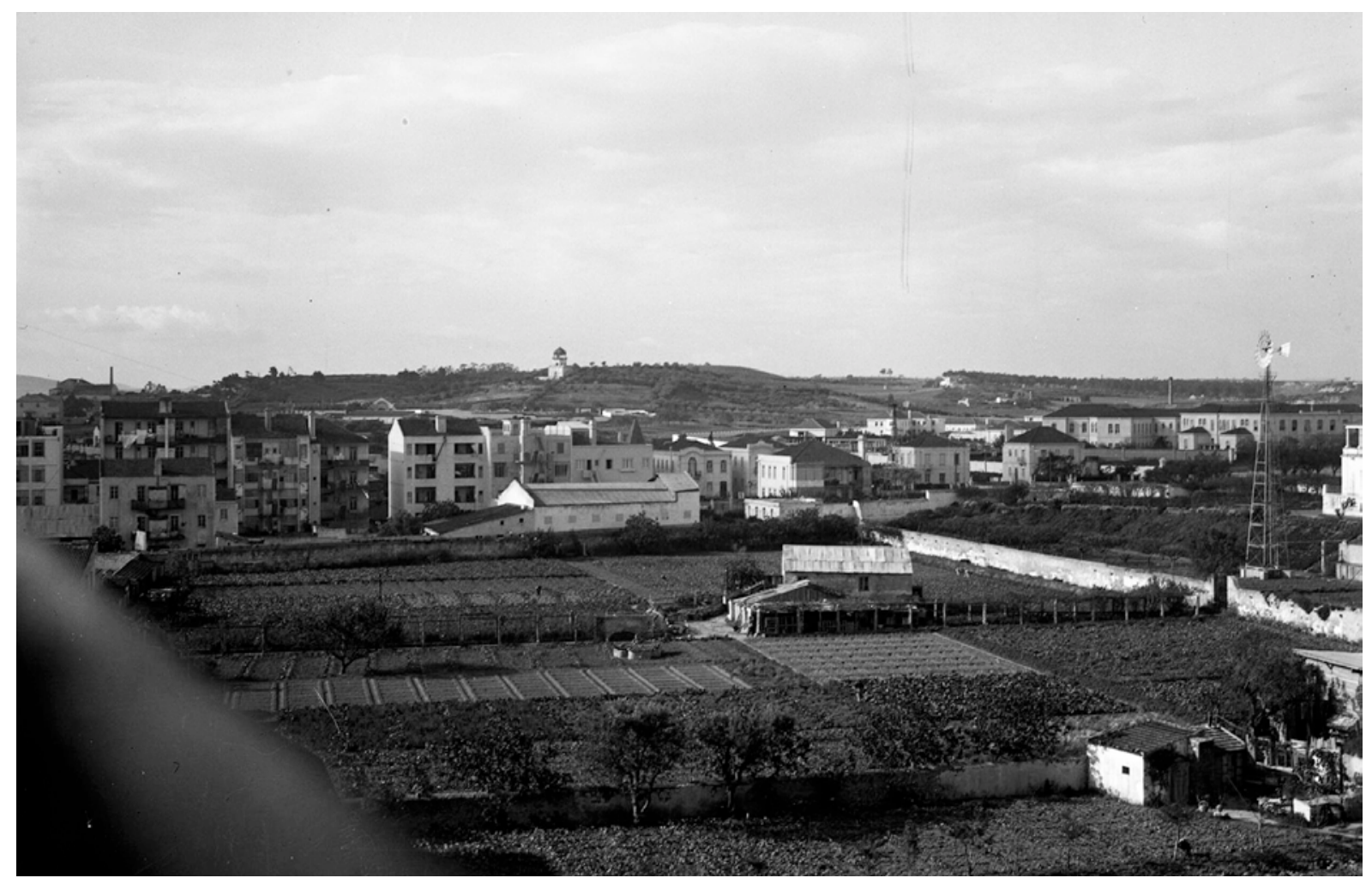

Figure 2: “Campo Grande area: still cultivated in the 1940’s. 1945. Eduardo Portugal (C) Arquivo Municipal de Lisboa."

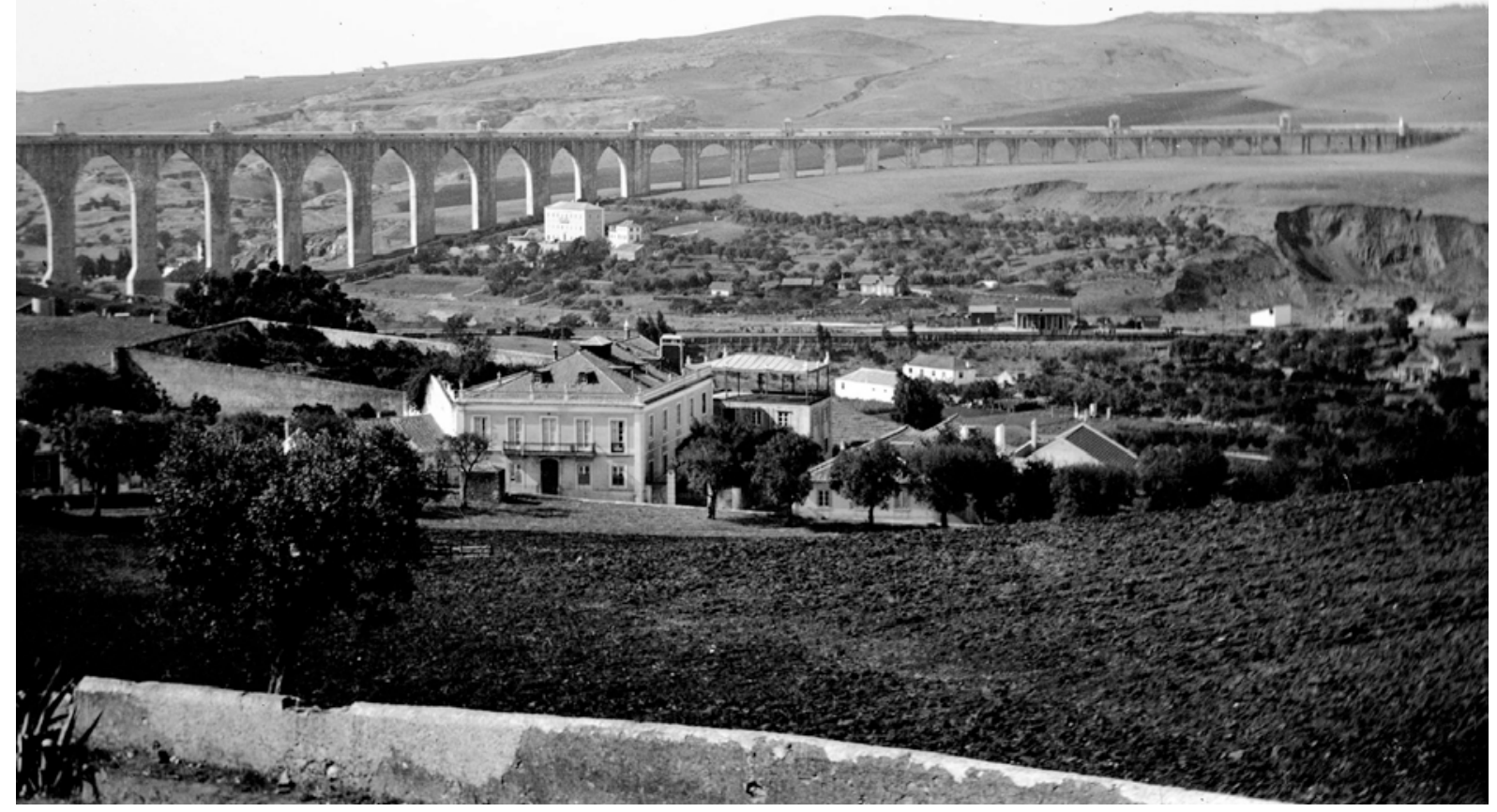

Figure 3: "Alcântara valley: production spaces near the city centre, around 1930. Casa Fotográfica Garcia Nunes (C) Arquivo Municipal de Lisboa.” 
On a regional scale, food production areas around Lisbon resembled von Thünen's model, with fruit and vegetable produce closer to the city centre, followed by vineyards, grain cultivation and cattle rearing (Trindade and Gaspar quoted by Paquete, 2001: 34). The predominance of vegetable gardens, vineyards and olive groves in the eastern part of the city's productive belt, and ploughed lands in the western part, could be identified (MEMO, 2014). These production spaces were interwoven with built spaces and were found not only within the limits of the city, but almost up to its centre.

Despite these extremely productive surrounding lands (which rendered people from Lisbon the nickname of alfacinhas, 'little lettuces'), Lisbon was never self-sufficient, depending on food imports from the remaining country (from Estremadura and Algarve provinces, for example) and from the rest of the world. Although, historically, there were four important terrestrial routes through which local produce reached the city - the roads of Xabregas, Arroios, Andaluz or Portas de Santo Antão, and Alcântara (Paquete, 2001: 43) — the river played a crucial role in the city's food distribution (Fig. 4). Since fluvial and sea routes were the easiest and cheapest ways of transport, food products arrived through the Tagus from both distant sources and national provinces, like the Northern ones and Algarve. Products were discharged at specific points on the riverbank, depending on food type, and lent their names to these places, persisting toponyms such as Cais do Trigo ('Wheat's Wharf) and Campo das Cebolas ('Field of Onions') (figure 4). Notwithstanding Lisbon's strong navigation vocation (which provided its main income for more than 300 years), the proximity to local food supplies remained an important factor for managing both urban and peri-urban spaces (Pereira dos Santos, 2010: 52). This organization was closely linked to the territory and its productive potential, being characteristic of a strongly rural society (Pereira dos Santos, 2010: 52). 


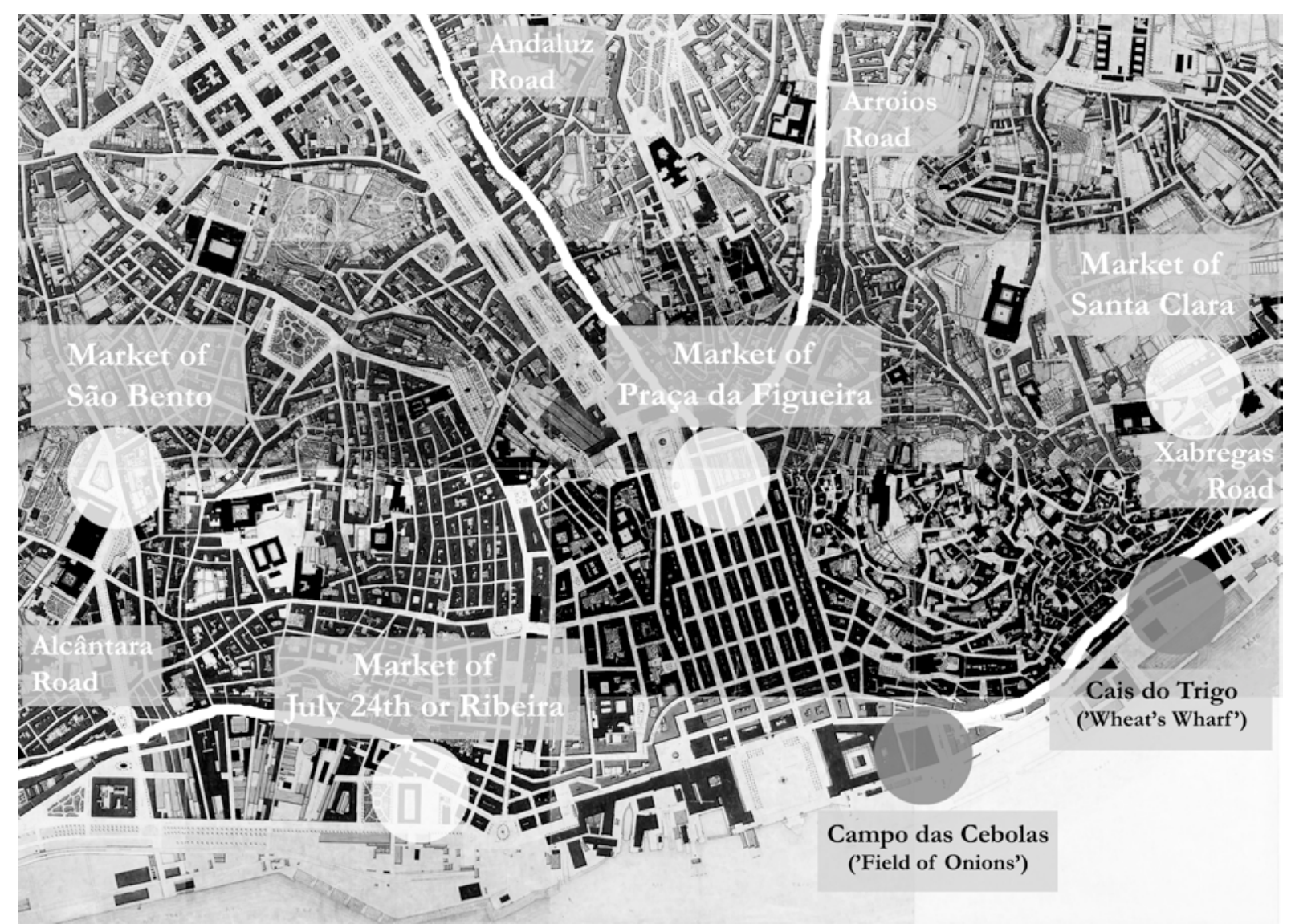

Figure 4: "Distribution Spaces and Markets in Lisbon (C) Mariana Sanchez Salvador."

Although there had been several open-air markets (such as the one at Rossio, one of the main squares today), by this time a network of markets and fairs, along with food shops that had started to populate the city, dominated the food retail spaces. These shops often combined food trade with other products or with food consumption and, by 1910 , nearly $45 \%$ of the 17418 existing shops were connected to food retailing - mainly of wine, groceries, meat and bread (Alves, 2017: 10). The cartographic map of 1911 also shows a set of market buildings inaugurated during the previous decades, carefully located close to food drop-off spots and associated with the surrounding neighbourhoods. Among these, one can find the São Bento Market (1881), formerly located by the Parliament; the Market of July $24^{\text {th }}$ or Nova Ribeira (1882), which replaced the former Ribeira Velha Market, by the river (Fig. 5 and 6); the Market that existed at the current Figueira Square (1885), where two land routes joined (Fig. 7), Santa Clara Market (1887) and Alcântara Market (1905), located next to Alcântara-Terra train station, where Avenida de Ceuta was later opened (Fig. 8) (CML, 2016: 21-22). The construction of these markets was part of the city's modernization, which, among other things, implied moving food trade to more hygienic enclosed market buildings (market halls), a process parallel to other 
European cities (Parham, 2015: 79). This network was also complemented by informal trade, namely of fish, vegetables and fruit, by the river (Fig. 9).

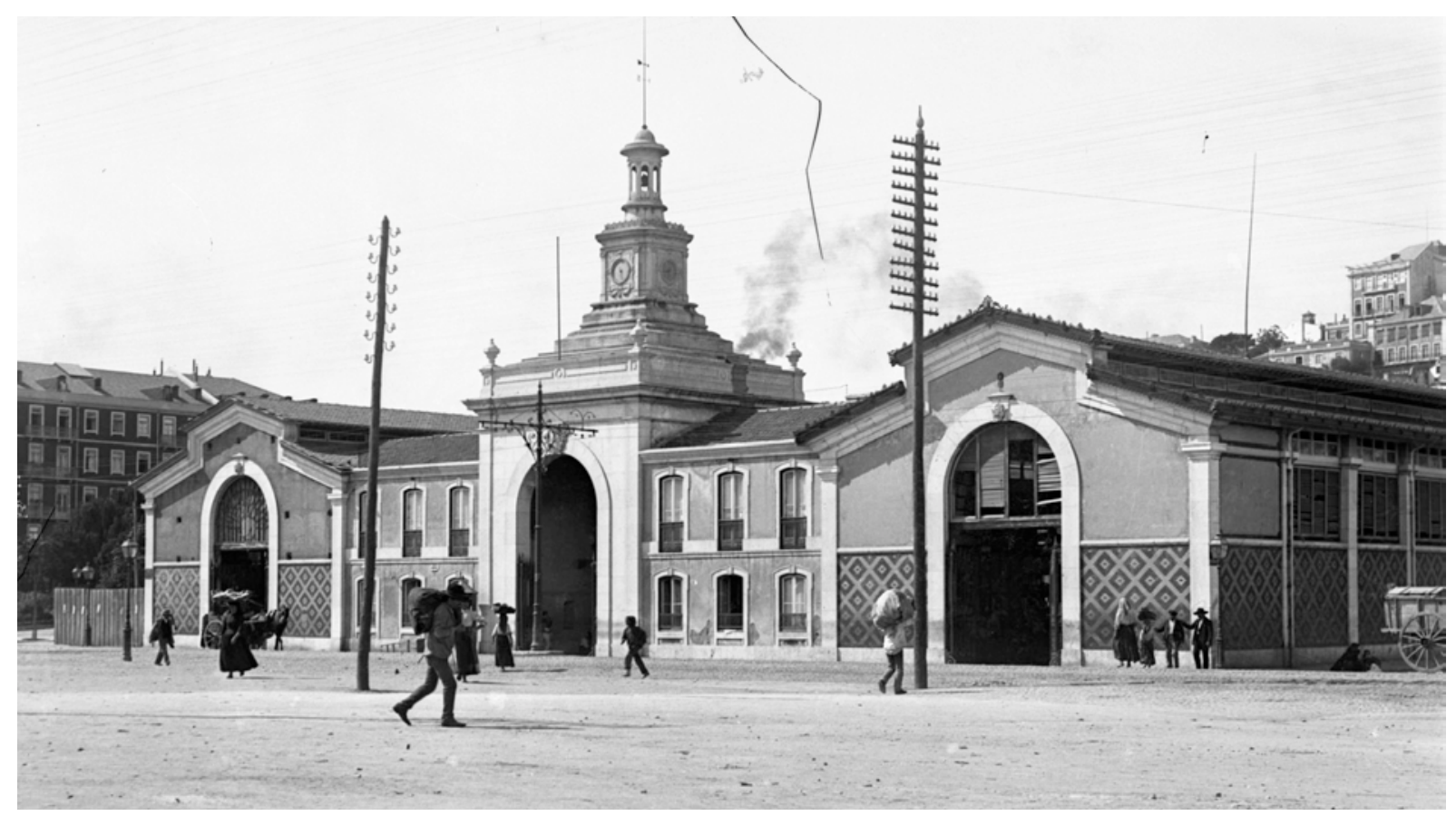

Figure 5: "Market of July $24^{\text {th }}$ or Nova Ribeira. Unknown author @ Arquivo Municipal de Lisboa."

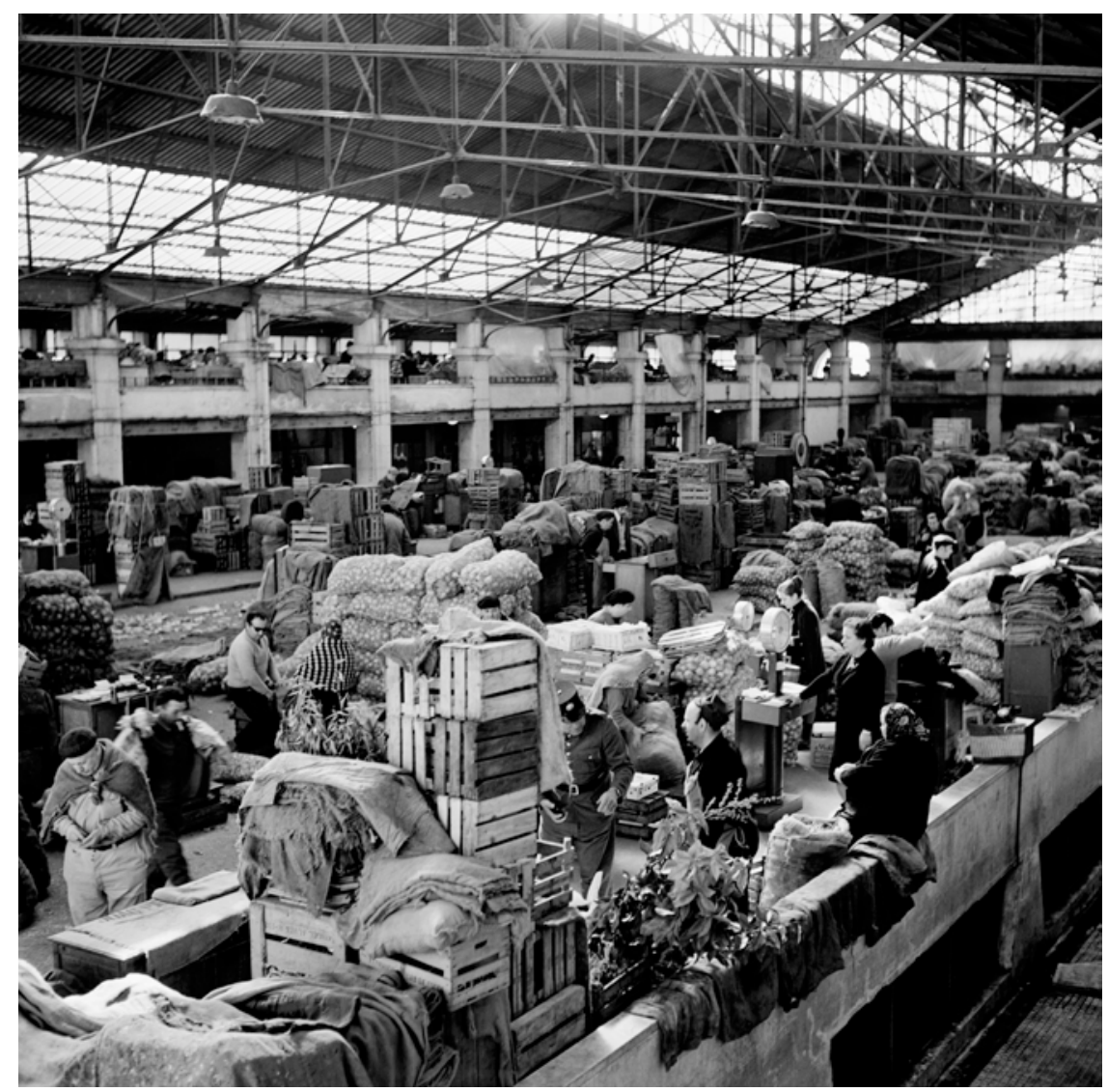

Figure 6: "Market of July $24^{\text {th }}$ or Nova Ribeira: interior. 1940-1970. Artur Pastor (C Arquivo Municipal de Lisboa." 


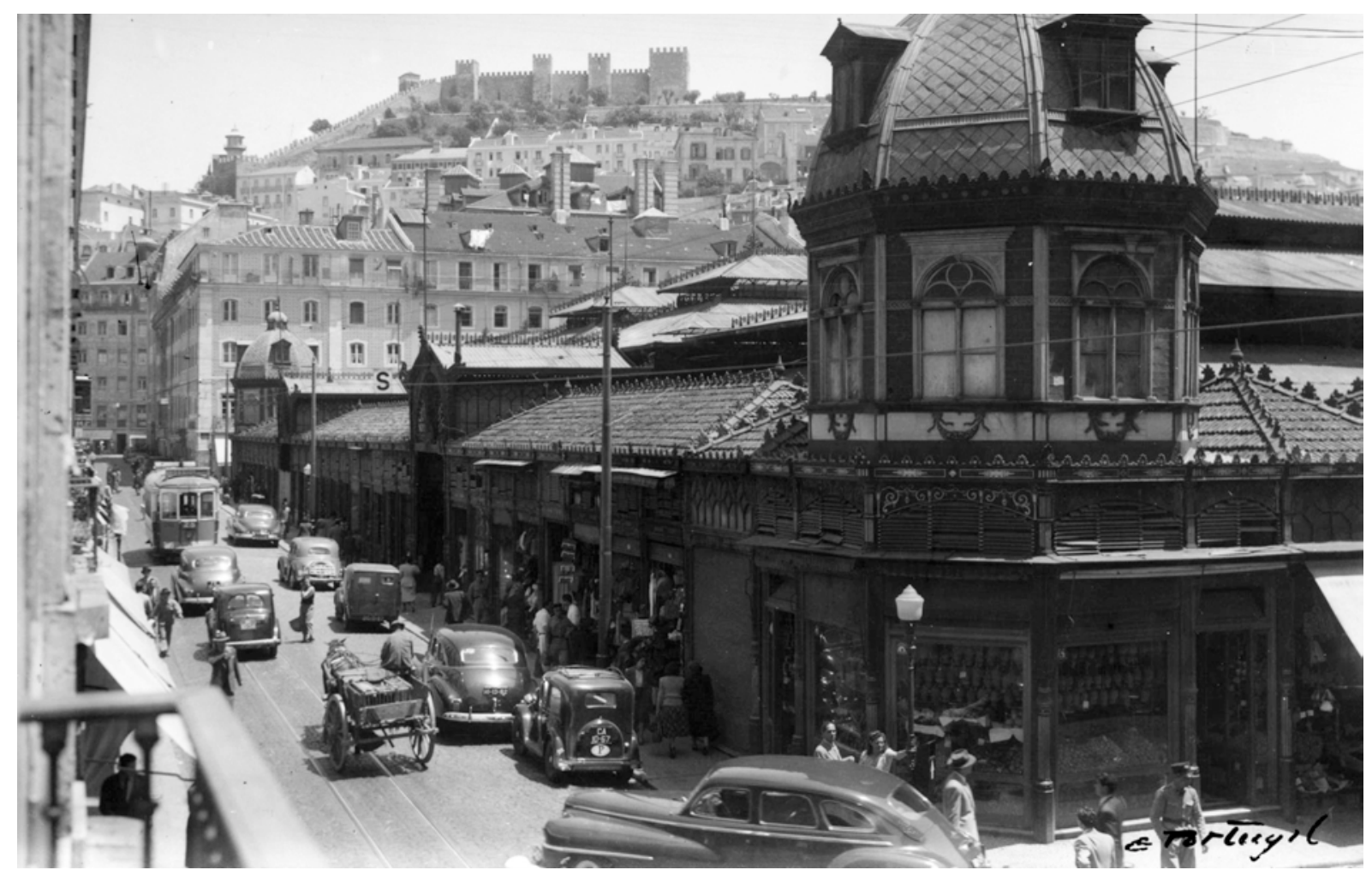

Figure 7: "Market of Praça da Figueira. 1948. Eduardo Portugal @ Arquivo Municipal de Lisboa."

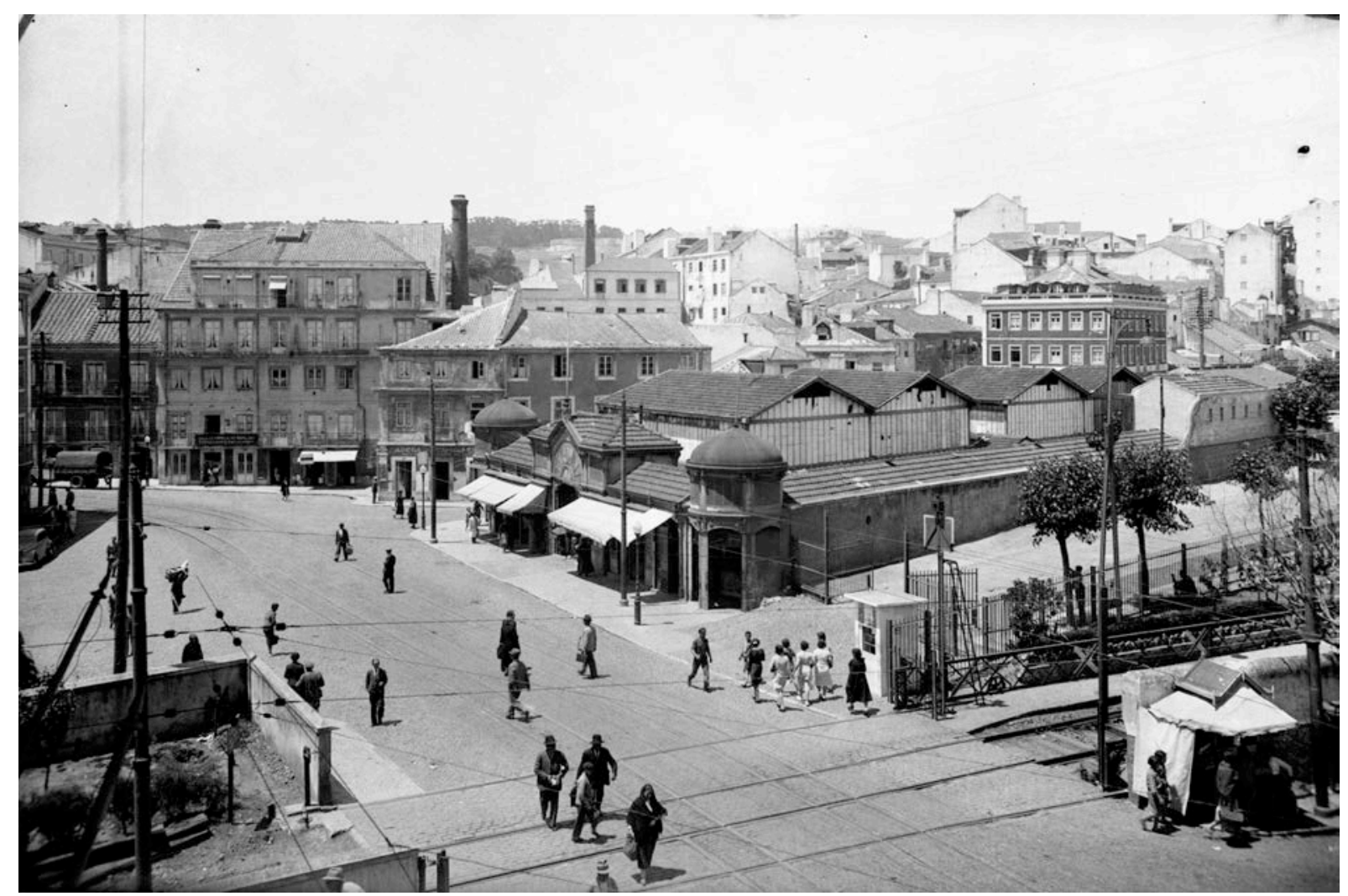

Figure 8: “Alcântara Market. 1940. Eduardo Portugal (C) Arquivo Municipal de Lisboa.” 


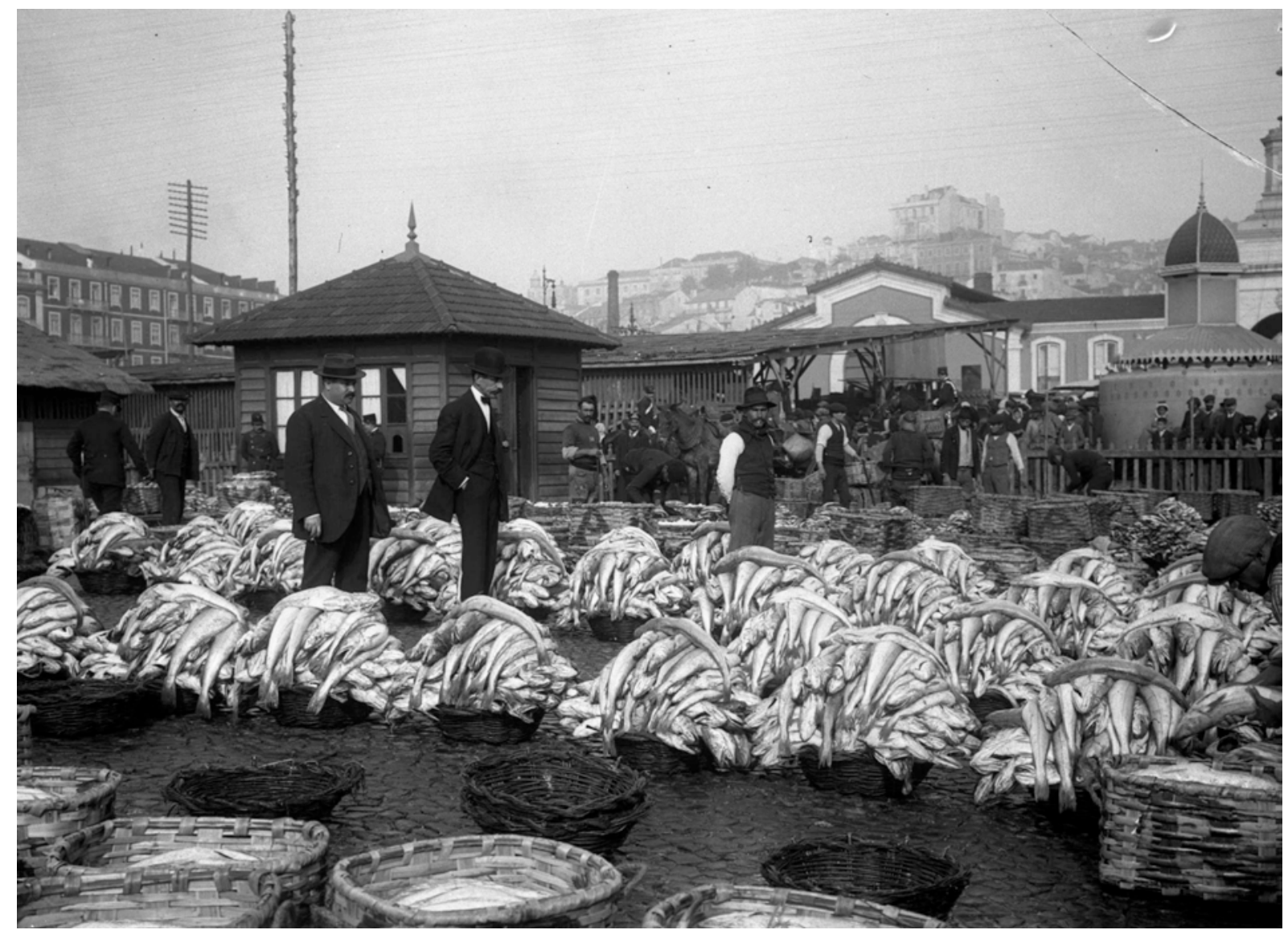

Figure 9: "Fish Sell by Ribeira Market. 1906. Joshua Benoliel @ Arquivo Municipal de Lisboa.”

During this period, there was an important presence of cattle in the city, including breeding, trade and slaughtering. The Municipal Slaughterhouse of Lisbon (Fig. 10 and 11), inaugurated in 1836, was located at Picoas until its closure in 1955. It was supplied by the General Livestock Market (Fig. 12), located at Avenida da República, in Entrecampos. In the early $20^{\text {th }}$ century, there were also itinerant butchers and still about 200 dairies, where fresh milk could be bought and drunk by the glass (Radich, 2007: 103). Dairies, as the roaming of cows and goats (Fig. 13), would only be forbidden by law in 1920 (Radich, 2007: 104). 


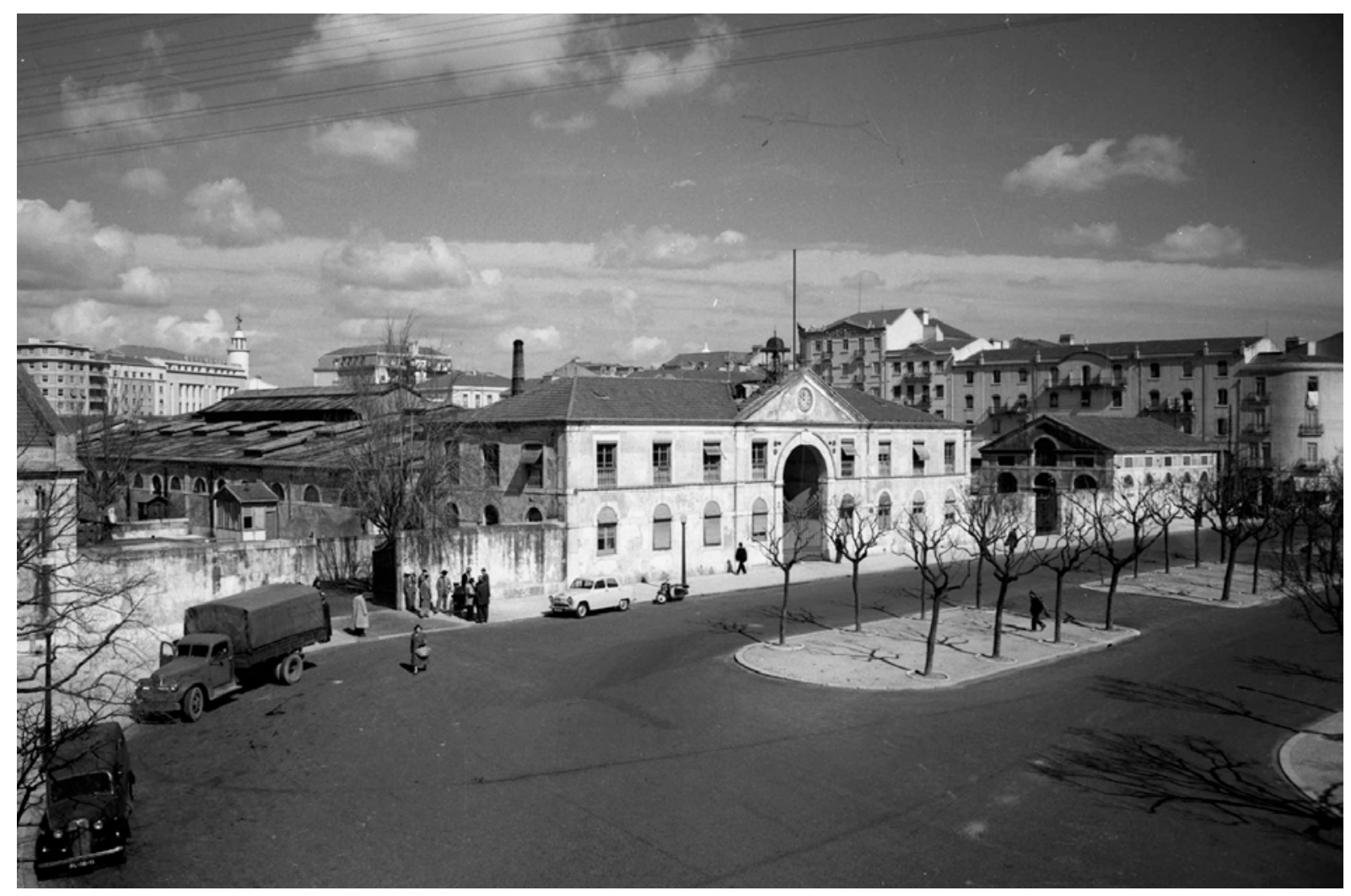

Figure 10: "Municipal Slaughterhouse of Lisbon. 1955. Armando Maia Serôdio @ Arquivo Municipal de Lisboa."

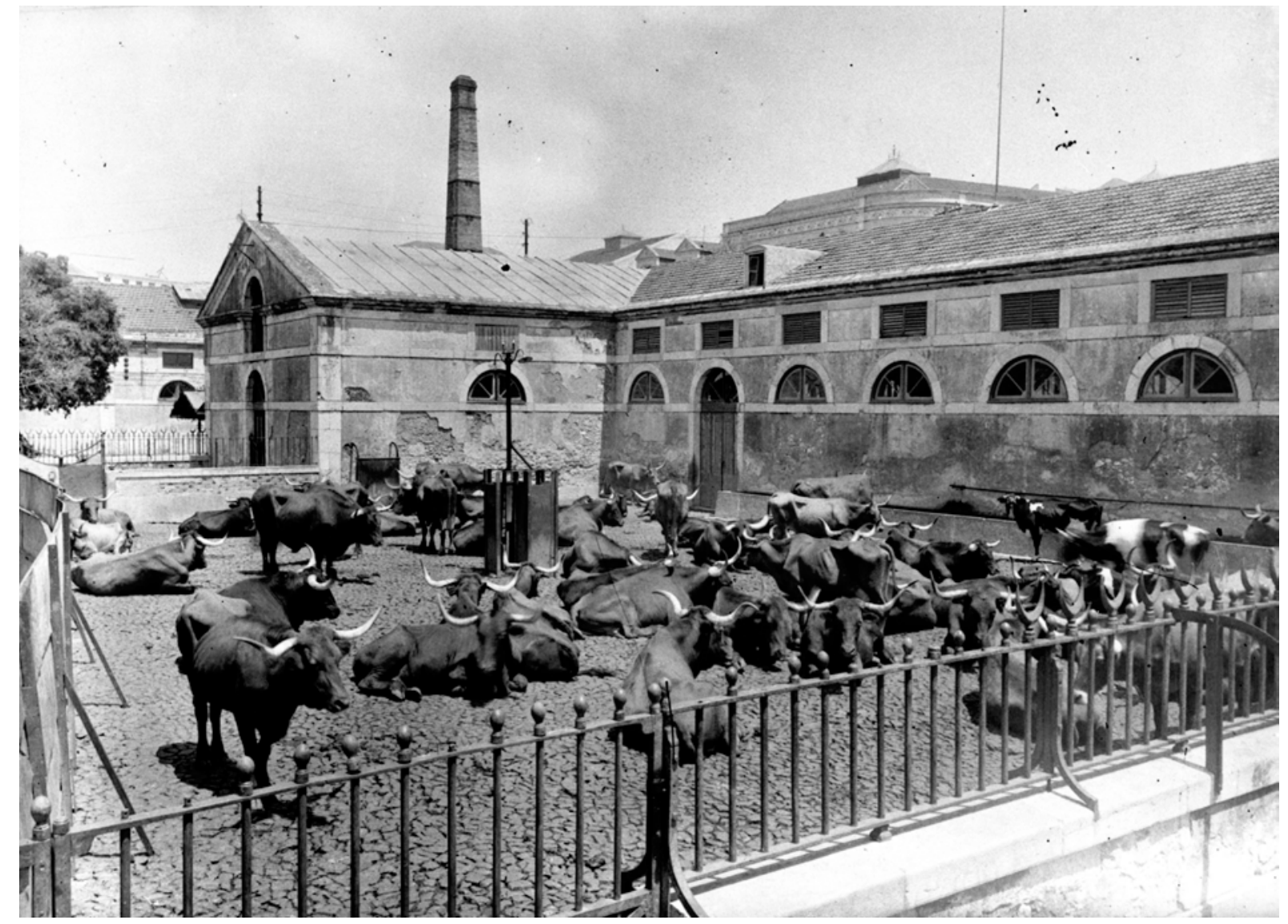

Figure 11: "Municipal Slaughterhouse of Lisbon. 19--. Filipe Morgado Romeiras @ Arquivo Municipal de Lisboa." 


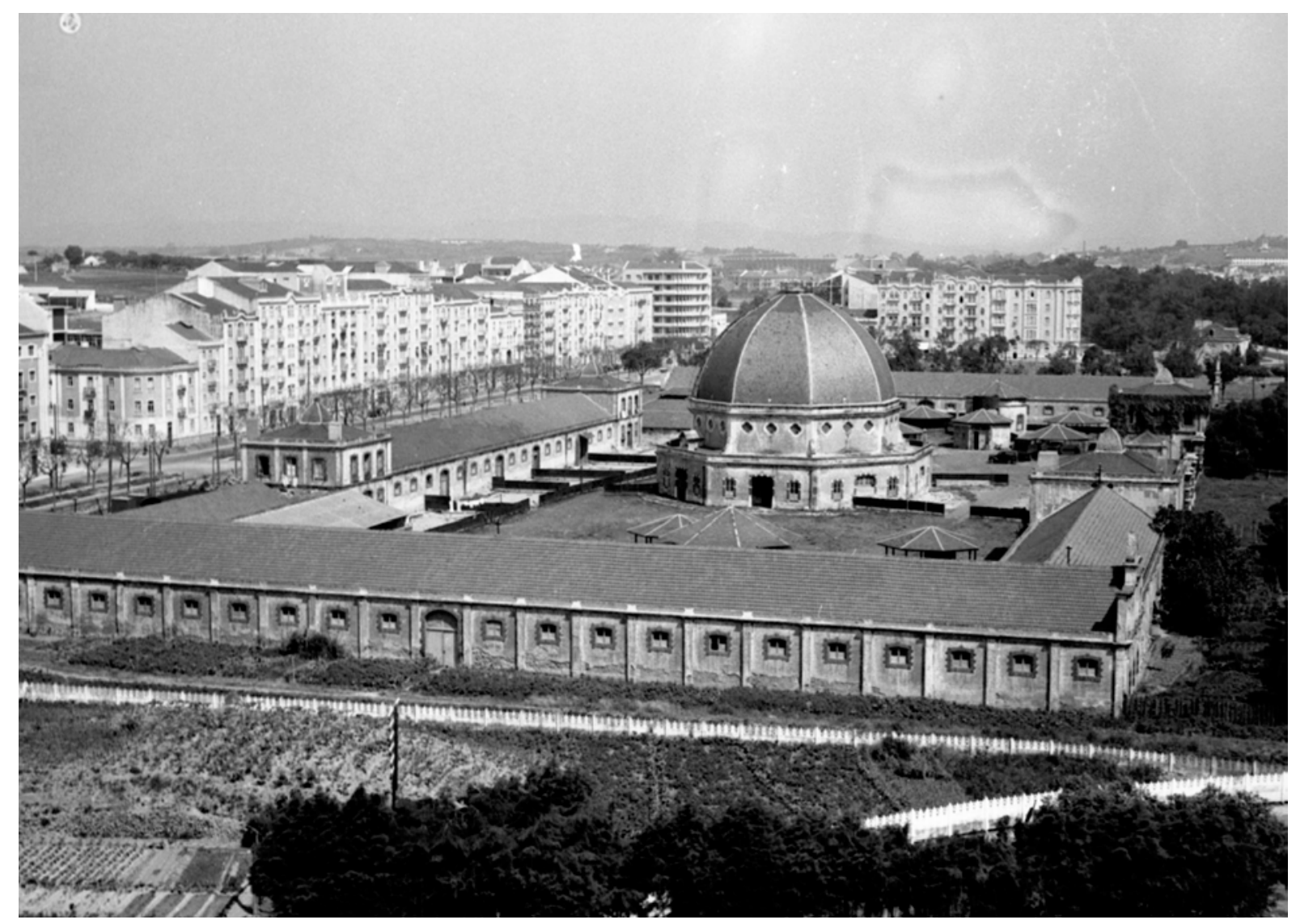

Figure 12: “General Livestock Market. 1950’s. Joshua Benoliel @ Arquivo Municipal de Lisboa.”

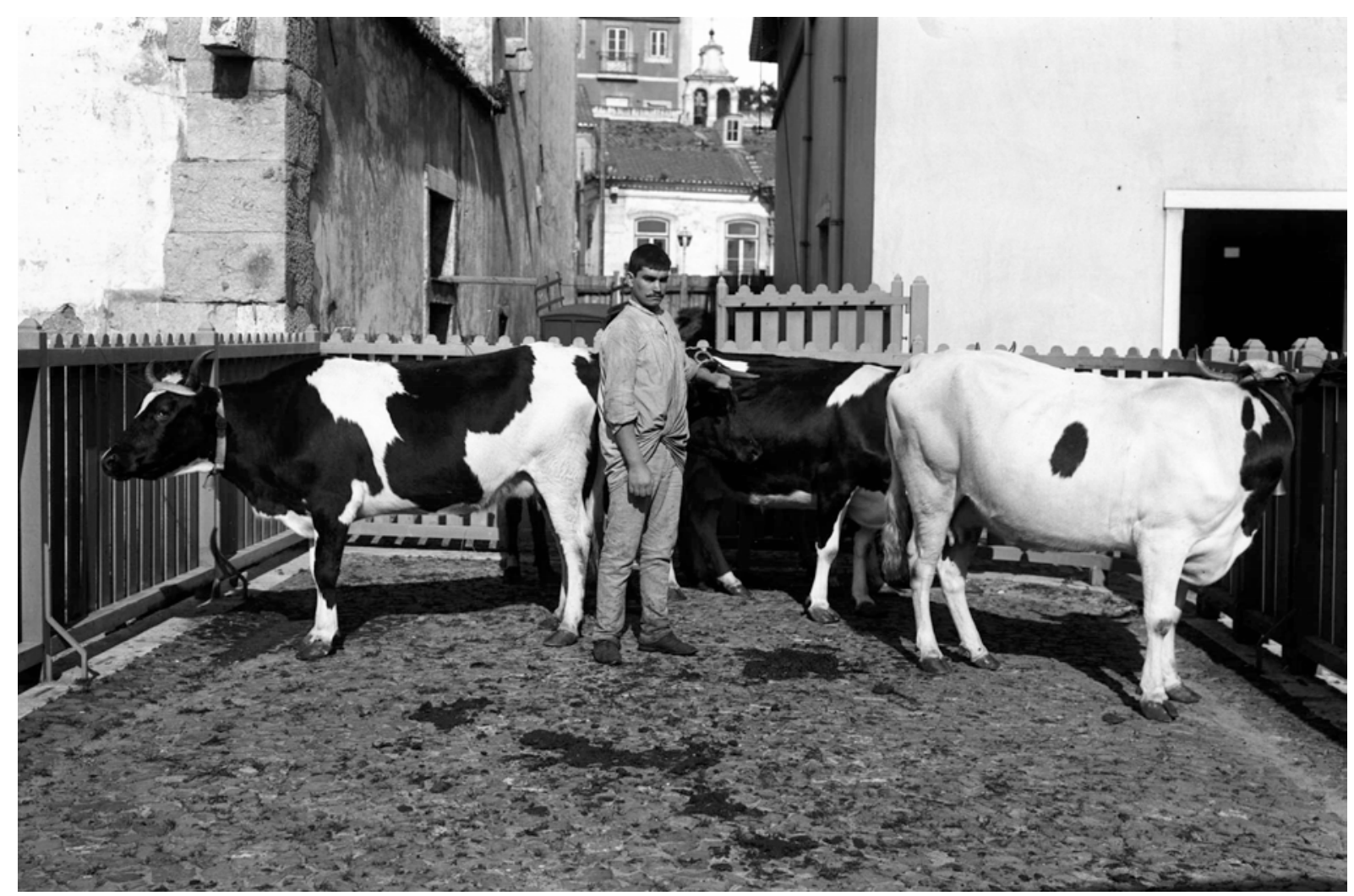

Figure 13: "Milk Seller. 19--. Paulo Guedes (C) Arquivo Municipal de Lisboa." 
We can, therefore, identify in early- $20^{\text {th }}$-century Lisbon features — such as location, organization of productive lands, food routes turned into important streets, market grounds into public squares —, which resemble the ones described for other historical cities. These stem from a previous pre-industrial relation between city and food and were starting to change.

\section{The Foodscape of Lisbon in the early $21^{\text {st }}$ century}

The current reality is quite different. The municipality was densely urbanized (figure 14), with most former food production areas built over by buildings and infrastructures. Due to this urban expansion, the memory of historical farms persists only in the names of newly built massive housing projects. The small sections that still linger constitute exceptional values in the city's landscape, preserving pieces of nature within an apparently randomly built fabric (Telles, 1997: 49).

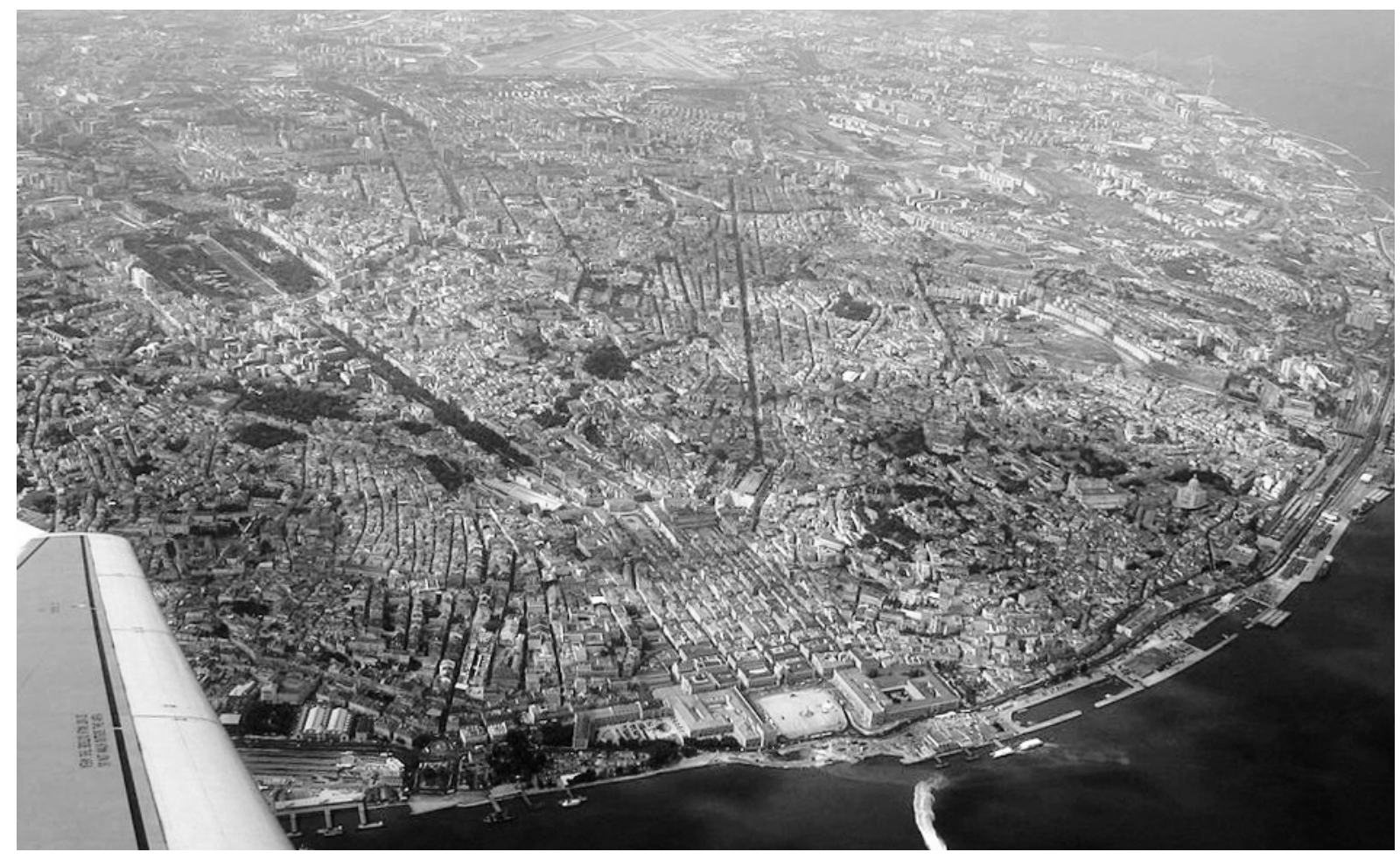

Figure 14: "Aerial view from Lisbon. 2006. The built-up fabric now covers almost the entire municipality. (C) António M. L. Cabral.”

Within the city's green spaces, only a residual part still fulfils a productive function. In total, urban agriculture (divided by the municipality into 'social vegetable gardens', 'leisure vegetable gardens', 'collective leisure vegetable gardens' and 'pedagogical vegetable gardens') occupied, in 
2008 , only $1.6 \%$ of the city's area -75.5 ha taken by urban vegetable gardens and 53.9 ha by undifferentiated agriculture (CML, 2015: 45-46).

"In Lisbon, intra-urban, microscale agriculture is widely practised in inner yards, where oranges, tangerines, dates and even bananas and avocados are often grown, in conjunction with subsistence horticulture.” (Madaleno, 2001: 4)

Scattered around and within the city, these 'hortas' are private or belong to the municipality, being periodically distributed through applications to local residents. The municipality also periodically grants free courses on production techniques and machinery in its Garden School (CML, 2018b). Depending on the horticultural park, each plot assigned may have from 50 to $150 \mathrm{~m}^{2}$ (CML, 2018a), though in some neighbourhoods some may have $25 \mathrm{~m}^{2}$. Urban vegetable gardens play an informal role - whether for leisure and pedagogic activities and strengthening of community ties, or to complement the livelihoods of a few households, through products or extra income from selling them (CML, 2015: 45) — rather than having a real relevance in the city's food supply. The production spaces that now feed Lisbon encompass the whole globe.

Food distribution is assured by a complex multi-way transport system, through which products arrive from all over the world. It often occurs off-hours — late night or dawn — seeming food products to 'pop up' in retail spaces (pers. obs.). This invisibility promotes a gradual disconnection between consumers and food systems. People are often unaware of where, by whom and how these food items are produced; a disconnection which is promoted by the increasing physical distance between the city and production spaces, granted by processing, refrigeration, transportation and cheap energy (Paxton, 2011: 23; Francis et al, 2005: 60-62).

Within retail spaces, supermarket and hypermarket chains are highlighted, possessing numerous locations throughout the city, with different sizes and 'concepts', some closer to the character, location and dimension of neighbourhood groceries, while others bet on size, quantity and variety (pers. obs). The network of traditional markets, extended between the 1940s and 1990s to keep up with the emergence of new neighbourhoods (CML, 2016: 23-25), gradually lost importance in supplying Lisbon. These buildings are now being reclaimed for new leisure-related uses: restaurants, gourmet food stalls, with hip food specialties (pastries, cheeses, preserves). As in other cities (Esperdy, 2002), markets become anchors for urban revitalization and connections with the neighbourhoods and communities (CML, 2016: 17-18), even though the new uses may obscure the original functions, which now operate at different schedules and areas, when they are maintained at all (Fig. 15). 
Lisbon's current mainstream foodscape presents, therefore, features similar to so many other developed cities: food supply is mainly insured by big distributers, which reflect on the secondarization of food production land use within the city, on the transportation means used to bring food products in and on the overall retailing landscape, with supermarkets dominating food trade.
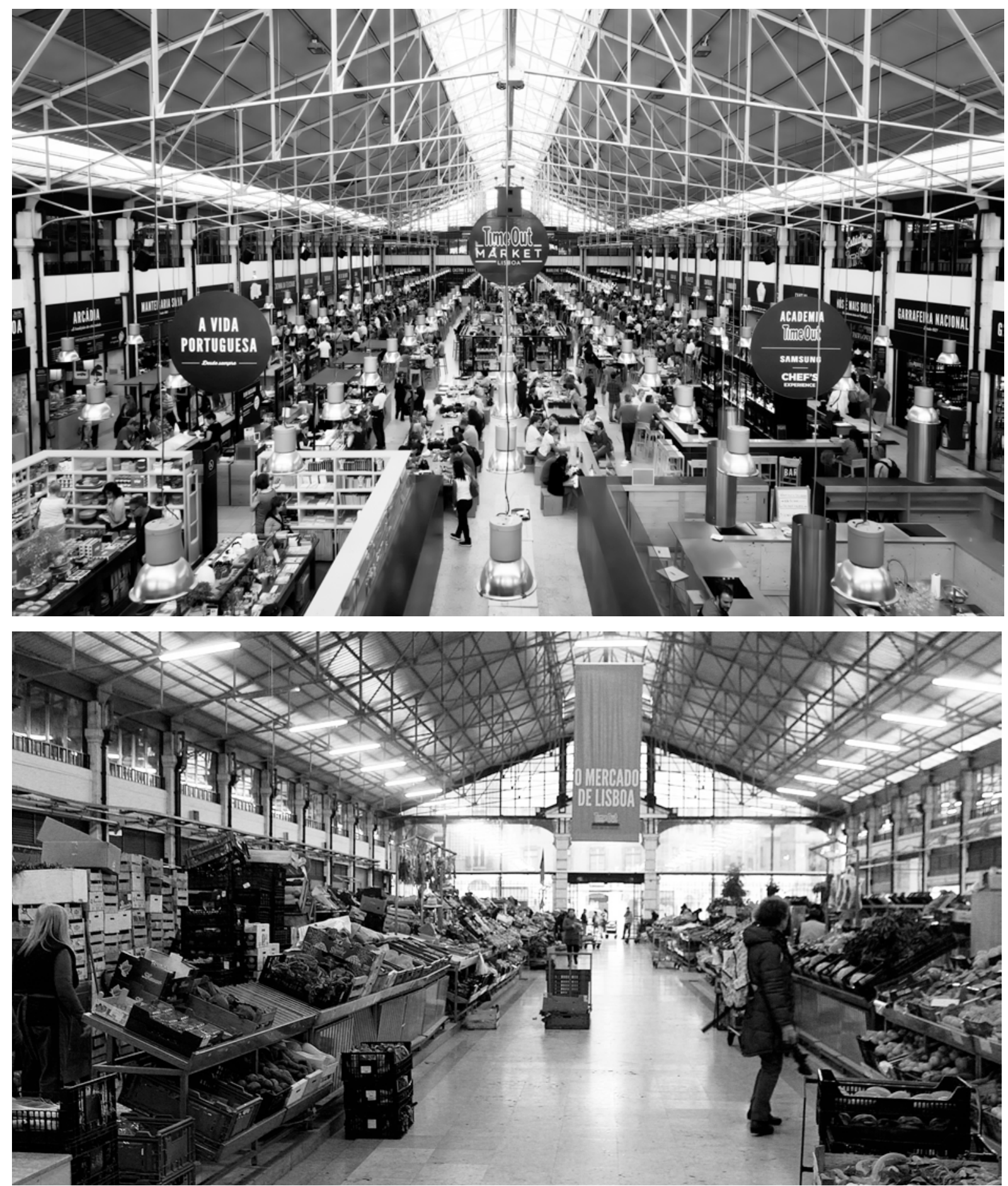

Figure 15: "Time Out Market Lisboa at Ribeira Market and the old Ribeira Market, still existing next to it. 2017. Enrico Strocchi and Dguendel @ Enrico Strocchi/Dguendel.” 


\section{New Tendencies: alternative Lisbon's foodscape}

In the face of this current reality, shaped by modern conventional food systems, we also witness the emergence of alternative food systems in Lisbon, which in turn compose alternative foodscapes. More people are cultivating their own food products, either at municipal horticultural parks (CML, 2018a), or their own private gardens, balconies or even simple vases. In magazines and social media, courses on how to cultivate certain vegetables, herbs, etc. multiply (pers. obs). Public schools are developing programs, workshops and activities around vegetable gardens within their premises (Fig. 16), which are recognized and supported by Lisbon's City Hall and the Ministry of Education. While these are often nothing but a hobby, it signals a re-connection with food production, local resources and weather conditions.

While traditional markets are being revamped, a number of farmers' markets have re-emerged in public spaces, usually favouring products from specific regions (such as Mercado Lx Rural with Western Estremadura products) or organic productions (like Príncipe Real or Campo Pequeno). These initiatives meet the growing consumer concerns regarding health and sustainability, but also support local economies. The phenomenon was also propelled by the recent economic crisis, since the consumption of local products was encouraged to help the country's economy (a strategy promptly embraced by supermarkets in response to consumers' demands, while improving their social image and profits). Meanwhile, as part of the Municipal Market Plan of Lisbon (CML, 2016), the Market of Lumiar was turned into the first indoor market exclusively devoted to national organic produce (CML, 2018c).

Another growing concern has been food waste, which in Lisbon triggered a set of innovative initiatives, which even made the city a case study for the United Nations (Costa, 2014). Fruta Feia ('Ugly Fruit'), for example, prevents food waste at farm level, by collecting off-size produce, or not matching aesthetic criteria defined by retailers, despite fulfilling food safety and quality standards. Fruta Feia collects these products and sets 'baskets' that may be picked up in several delivery points across the city (figure 17). The project has expanded from Lisbon, to Oporto, Parede, Gaia and Matosinhos, and is estimated to weekly prevent 10 tons of waste (Fruta Feia, 2017). 


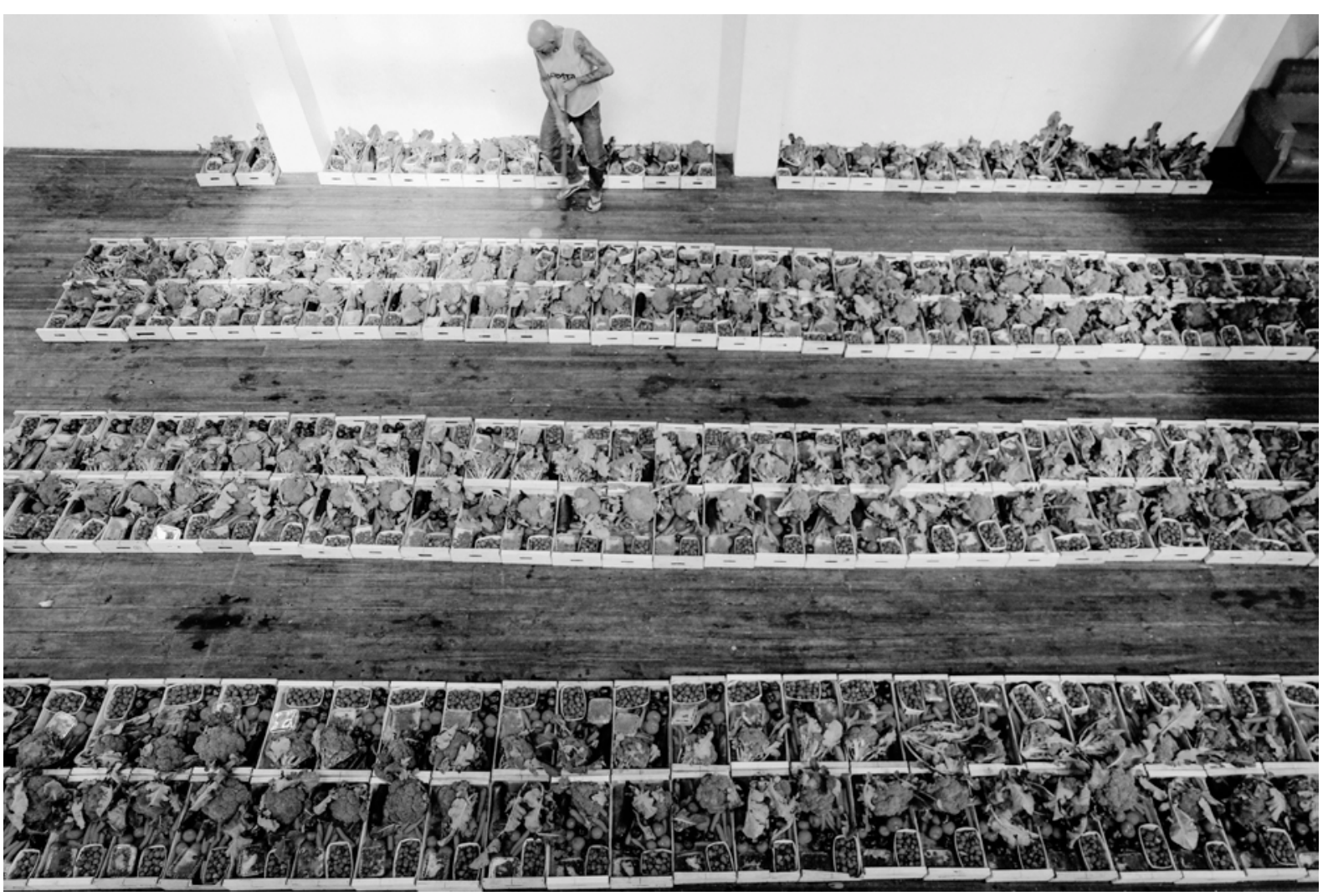

Figure 16: "Fruta Feia. 2018. Guilherme Tosetto @Fruta Feia."

Another interesting project is Refood, which redirects unconsumed meals from cafés, supermarkets, restaurants, school canteens, etc. to families in need. The system is based on volunteers who collect, pack and handle over meals to families at each headquarter, in previously defined schedules (Refood, 2017). Volunteers and families both inhabit the same area as the donating institutions, which promotes neighbourly relations (pers. obs.). Today, Refood (2017) has 25 headquarters in Portugal (one in almost every neighbourhood in Lisbon) and totals 4000 volunteers, 900 supplying partners, and 46000 meals delivered each month (Fig. 18).

At a more institutional level, the association Zero Desperdício ('Zero Waste') re-directs food surplus from institutions (municipal entities, schools, companies and hotels) to other associations and/or families in need. They estimate to have dealt with about 4211160 meals so far (totalizing over 2000 tons of prevented food waste and over 10 million euros) from 546 entities, delivered to 7476 recipients (Zero Desperdício, 2017). Lisbon's City Hall has also raised awareness on the issue, by supporting several citizen initiatives and issuing a Municipal Plan against Food Waste, in January 2015. Later, the Portuguese Government also declared 2016 the National Year of Combating Food Waste. 


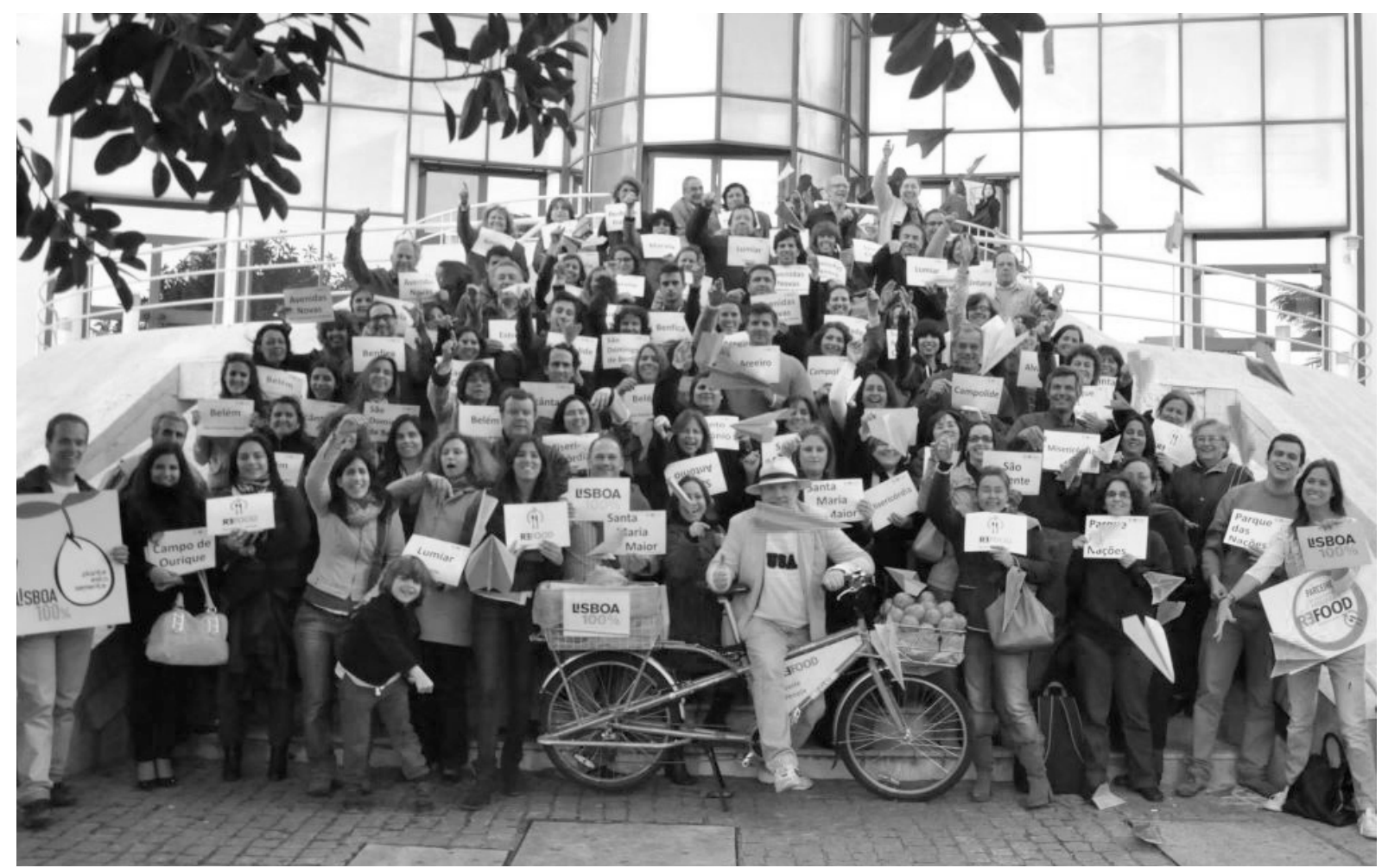

Figure 17: "Refood: Meeting with representatives from all the nuclei @ Refood."

We can witness in Lisbon an active effort by consumers to reconnect with dimensions of food systems beyond preparation and consumption, mainly through civic initiatives. Public institutions and policy changes often play a minor role in triggering them (although they may get involved later), while social media and digital technology have gained increased importance in shaping food systems. Paradoxically, these resources associated with global and virtual connection have actually been enabling more local food systems, by directly connecting producers, consumers, projects, events and institutions, and by promoting shorter and stronger links between stakeholders.

While conventional modern food systems have managed to virtually erase the presence of food from public spaces - relegating it to enclosed and private spaces (Parham, 2015: 146-147) and dislocating production to remote sites and distribution to invisible hours - these alternative initiatives have brought food back into the public realm. These alternative projects, events and communities are the ones that still enable us to refer to a foodscape at the city scale.

Some initiatives found in Lisbon are innovative, and might help other cities to tackle the same type of issues. On the other hand, cities across the globe have developed their own strategies (Moragues et al, 2013; Viljoen, Bohn \& Howe, 2005; for example) and can also provide 
interesting case studies for Lisbon. It is only through sharing knowledge and experiences that the full potential of cities to tackle unsustainable food systems will be fully attained.

\section{Future Urban Foodscapes}

Even in a world where globalization, immaterial flows of information and digital resources thrive, food is still physical and local. Food combines and integrates knowledge from different areas, scales of intervention and stakeholders priorities, while having the ability of taking immaterial forces and ground them into space. Food impacts urban health, environment and metropolitan economies, while connecting important systems such as housing, transports or land use (FAO, 2011: 16; Pothukuchi \& Kaufman, 1999: 213-214). Food matters are reflected in social equality, environmental sustainability and economic dimensions. Yet, food hasn't been prioritized in designing and managing cities.

Considering that food is a basic need — along with shelter, air, water, which have been intrinsic parts of urban planning (Morgan 2009) - then food resilience should become a priority in urban design and management. Relying on distant sources, numerous (private) intermediaries and cheap fossil fuels seems irrational and, ultimately, inefficient, since food is not reaching everyone, even in cities, while at the same time many cities face challenges regarding public space deterioration. The development of more sustainable urban foodscapes is therefore imperative, and urban design can contribute to solve these challenges, by becoming the medium through which cities and food merge into a sustainable and lively reality.

"Food [...] is central to urbanism, because it is so critical to creating and maintaining this vitality, complexity and intimacy, because it can help make and support walkable, mixed, human-scaled and diverse places and because it can increase the focus of urban space on the public realm.” (Parham, 2015: 2)

Though cities pose specific challenges to food systems, they also hold an exceptional potential, which has been expressed by the Milan Urban Food Policy Pact (MUFPP, 2015) and by several innovative food projects in urban areas all over the world (Moragues et al, 2013; Viljoen, Bohn \& Howe, 2005; for example, among others).

Parham (2015: 180-181), quoting several authors, argues that architects and planners should bring forgotten food solutions back into the city, while designing better food spaces. In this sense, as described, dealing with foodscapes is about looking at reality through a 'food lens', which entails perceiving the built reality as the materialization of flows (between where food is produced 
and bought/consumed), of economic factors and social movements, of balancing natural features (soil fertility, orography, weather conditions) with other urban priorities. This 'visual tool' for seeing the city as a foodscape might be useful for urban design processes, especially when considering that most instruments, investments and infrastructures required to bring food into the city are already in place.

The importance of green structures in this context is consensual. Urban planning already dictates the need for green spaces and ecological structures, and resorts to trees and vegetation to manage urban temperature, air quality, health and quality of life. But this prescribed land use could have a multifunctional and dynamic character, while also being productive, with horticultural areas within urban parks, and using fruit trees along the streets, instead of merely decorative ones. This vision fits the concept of CPUL's (Continuous Productive Urban Landscapes) proposed by Viljoen, Bohn \& Howe (2005), which would result on several environmental and social benefits for cities.

Public transportation could also be articulated with food distribution, to ensure the flow of food products off-hours and its networks (roads, tracks) should be designed taking into consideration these flows between food production and consumption areas, besides connecting residential and working districts. Public spaces could include covered areas to provide shade and protection, and access to water infrastructure to host periodic food markets. In planning instruments, the mix of food activities within the neighbourhood could be enhanced, so that every inhabitant could come across food production, artisanal processing, retailing, etc. within a short radius, strengthening their ties with the community and the food system as a whole.

When looking at a city through the lens of food, some design solutions for urban form elements — open (public or private) spaces, streets and buildings - emerge as facilitators, enabling and empowering flows of products and people, while others carry entropy, or even block them. This foodscape approach can be, thus, not only used as a factor in urban design, but also to assess and improve proposed solutions.

This vision is still not a reality in the case of Lisbon, even though the described alternative foodscape and some other projects emerging bring hope that it will be. Towards that goal, knowing the city's past and the evolution of its foodscape can bring helpful insights and justify certain paths. That's the end goal of this research: a contribution to the city's future. 


\section{Conclusion}

Drawing on the work of several authors, the interdependent relationship between cities and food systems has been described, a relationship shaped into foodscapes. In the last century, food systems have undergone the greatest transformations in history, transforming urban foodscapes in turn. In Lisbon, as in other cities, the transformation from an ancestral reality, linked to territory and local resources, into global supply systems is clear. City and food production spaces have become increasingly distinct and distant realities, with consequences for the environment, society and economy. Alternative trends have, however, emerged, reconnecting communities with different stages of food systems.

Food, as a basic need, can be a decisive factor in designing more sustainable cities. Guaranteeing food production and flows can help design and assess urban design solutions, since food combines and integrates different areas, scales of intervention, and stakeholders priorities. The role of architects in this context, as privileged actors in shaping the built environment, has started to be enhanced.

Designing and managing a city taking food systems into account can thus carry significant advantages on environmental sustainability, social equality and community ties, while enlacing economy. Sustainable cities cannot be attained without sustainable food systems, and knowing their past interaction, their historical urban foodscapes, is key for embodying lessons from the past, and project them into solutions for the future, for a truly sustainable (urban) development.

Note: all the translations from Portuguese to English were made by the author.

Acknowledgments: The author would like to thank Arquivo Municipal de Lisboa, Fruta Feia and Refood for making images available for this publication. 


\section{References}

ALVES, D. (2017) Shopkeepers and the city: the spatial economy of the retail trade in a European capital city (Lisbon, 1890-1910). History of Retailing and Consumption. p. 1-20.

ASCHER, F. (2010) Novos Princípios do Urbanismo; Novos Compromissos Urbanos: um Léxico. Lisbon: Livros Horizonte.

BJÖRKLUND, Annika. (2010) Historical Urban Agriculture: Food Production and Access to Land in Swedish Towns before 1900. Stockholm: Stockholm University.

BLUM-EVITTS, S. (2009) Designing a Foodshed Assessment Model: Guidance for Local and Regional Planners in Understanding Local Farm Capacity in Comparison to Local Food Needs. Master thesis in Regional Planning. Graduate School of the University of Amherst.

BRAUDEL, Fernand. (1992) Civilização material, economia e capitalismo, séculos XV-XVIII. Tomo I: As Estruturas do Quotidiano. Lisbon: Editorial Teorema.

BRITO, R. S. (1976) Lisboa: esboço geográfico. Boletim Cultural da Junta Distrital de Lisboa, 82. Lisbon: s.n.

CML. (2018a) Parques Hortícolas Municipais. [online] Available: http://www.cmlisboa.pt/viver/ambiente/parques-horticolas-municipais. [Accessed: 21 November 2018]

CML. (2018b) Escola de Jardinagem. [online] Available: http://www.cmlisboa.pt/viver/educacao/fora-da-escola/escola-de-jardinagem/formacao/cursos-e-workshops.

[Accessed: 21 November 2018]

CML. (2018c) Mercado do Lumiar especializado em produtos biológicos. [online] Available: http:/www.cm-lisboa.pt/viver/comercio/atualidade/detalhe/article/mercado-do-lumiarespecializado-em-produtos-biologicos. [Accessed: 21 November 2018]

CML. (2016) Plano Municipal dos Mercados de Lisboa 2016-2020. Lisboa: Câmara Municipal de Lisboa..

CML. (2015) Biodiversidade na Cidade de Lisboa. Uma estratégia para 2020. [online] Available: https://issuu.com/camara_municipal_lisboa/docs/biodiversidade_estrat_2020 [Accessed: 21 November 2018]

COSTA, J. (2014) Nações Unidas aprendem com Portugal a combater desperdício alimentar. Renascença, 14 April 2014. [online] Available: http://rr.sapo.pt/informacao_detalhe.aspx?did=144928 [Accessed: 29 September 2016] 
ESPERDY, G. (2002) Edible Urbanism. Architectural Design 72. p. 44-50. [online] Available: http://www.esperdy.net/wp-content/uploads/2009/03/Edible-Urbanism.pdf [Accessed: 22 November 2018]

FAO. (2011) Food, Agriculture and Cities: Challenges of food and nutrition security, agriculture and ecosystem management in an urbanizing world. Rome: FAO. [online] Available: http://www.fao.org/fileadmin/templates/FCIT/PDF/FoodAgriCities_Oct2011.pdf [Accessed: 19 September 2014]

FRANCIS, C.; LIEBLEIN, G.; STEINSHOLT, H.; BRELAND, T. A.; HELENIUS, J.; SRISKANDARAJAH, N. \& SALOMONSSON, L. (2005) Food Systems and Environment: Building Positive Rural-Urban Linkages. Human Ecology Review, Vol. 12, No. 1. p. 60-71. [online] Available: http://www.humanecologyreview.org/pastissues/her121/francisetal.pdf [Accessed: 03 November 2013]

FRUTA FEIA (2017) Fruta Feia - Início. [online] Available: http://www.frutafeia.pt/pt [Accessed: 9 September 2017]

GETZ, A. (1989) Urban Foodsheds. Letter to Peter Bird Martin. Institute of Current World Affairs. [online] Available: http://www.icwa.org/wp-content/uploads/2015/08/AAG-2.pdf [Accessed: 08 March 2015]

HEDDEN, W. P. (1929) How great cities are fed. New York: D. C. Health and Company. [online] Available: http://newruralism.pbworks.com/f/Hedden.pdf [Accessed: 03 March 2015]

KASTNER, T.; RIVAS, M. J. I.; KOCH, W. \& NONHEBEL, S. (2012) Global changes in diets and the consequences for land requirements for food. PNAS, vol. 109, no. 18. p. 68686872. [online] Available: http://www.pnas.org/content/109/18/6868.full.pdf [Accessed: 12 November 2016]

MADALENO, I. M. (2001) Cities of the future urban agriculture in the third millennium. Food, Nutrition and Agriculture. 29. p. 1-12.[ [online] Available: https://www.researchgate.net/publication/265409792_Cities_of_the_future_Urban_agriculture_ in_the_third_millennium [Accessed: 16 November 2018]

MEMO (2014) MEMO - Evolution of the Lisbon metropolitan area metabolism. Lessons towards a Sustainable Urban Future: Results (Selected). [online] Available: https://memoproject.wordpress.com/results/ [Accessed: 21 May 2015]

MORAGUES, A.; MORGAN, K.; MOSCHITZ, H.; NEIMANE, I.; NILSSON, H.; PINTO, M.; ROHRACHER, H.; RUIZ, R.; THUSWALD, M.; TISENKOPFS, T., \& HALLIDAY, J. 
(2013) Urban Food Strategies: the rough guide to sustainable food systems. [online] Available: http://www.foodlinkscommunity.net/fileadmin/documents_organicresearch/foodlinks/publicatio ns/Urban_food_strategies.pdf [Accessed: 21 May 2016]

MORGAN, K. (2009) Feeding the City: The Challenge of Urban Food Planning. International Planning Studies, 14:4. p. 341-348

MORRIS, A. E. J. (1995) Historia de la forma urbana: desde sus origenes hasta la Revolución Industrial. Barcelona: Ediciones Gustavo Gili.

MOUDON, A. V. (1997) Urban morphology as an emerging interdisciplinary field. Urban Morphology (1997)1. p. 3-10.

MUFPP - Milan Urban Food Policy Pact (2015). [online] Available: http://www.milanurbanfoodpolicypact.org/text/ [Accessed: 21 November 2015]

MUMFORD, L. (2004) A Cidade na História. São Paulo: Martins Fontes.

MUMFORD, L. (1970) The Culture of Cities. New York: Harcourt Brace Jovanovich.

MUMFORD, L. (1956) The Natural History of Urbanization. [online] Available: http://habitat.aq.upm.es/boletin/n21/almum.en.html [Accessed: 20 January 2014]

PAQUETE, M. (2001) Cozinha Saloia: hábitos e práticas alimentares no termo de Lisboa. Sintra: Colares Editora.

PARHAM, S. (2015) Food and Urbanism: The Convivial City and a Sustainable Future. London: Bloomsbury.

PAXTON, Angela. (2011) The Food Miles Report. Sustain. [online] Available: https://www.sustainweb.org/publications/the_food_miles_report/?section=21 [Accessed: 27 July 2018]

PEREIRA, J. C. (1915) A Propriedade Rústica em Portugal. Lisbon: Imprensa Nacional.

PEREIRA DOS SANTOS, H. (2010) Do Tempo e da Paisagem: Manual para a leitura de Paisagens. Parede: Principia.

POTHUKUCHI, K. \& KAUFMAN, J. L. (1999) Placing the food system on the urban agenda: The role of municipal institutions in food systems planning. Agriculture and Human Values, 16. p. $213-224$.

RADICH, M. C. (2007) Uma vaca urbana e cosmopolita. Ler História, 52. p. 95-126.

REFOOD (2017) Refood - Evoluçâo. [online] Available: http://www.re-food.org/pt/evolucao [Accessed: 9 September 2017]

STEEL, C. (2013) Hungry City: How Food Shapes our Lives. London: Vintage Books. 
TELLES, G. R. (coord.). (1997) O Plano Verde de Lisboa. Lisbon: Ediçóes Colibri.

UN-DESA. (2018) 2018 Revision of World Urbanization Prospects. [online] Available: https://www.un.org/development/desa/publications/2018-revision-of-world-urbanizationprospects.html [Accessed: 24 November 2018]

UNESCO (2011) Recommendation on the Historic Urban Landscape. [online] Available: http://portal.unesco.org/en/ev.php-

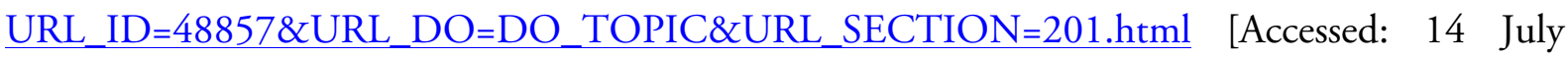
2014]

VILJOEN, A.; BOHN, K. \& HOWE, J. (2005) Continuous Productive Urban Landscapes: Designing Urban Agriculture for Sustainable Cities. Oxford: Architectural Press, Elsevier. [online] Available:

http://library.uniteddiversity.coop/Food/Continuous_Productive_Urban_Landscapes.pdf [Accessed: 19 February 2018]

VITRUVIUS, M. (2006) Tratado de Arquitectura: Os Dez Livros de Arquitectura. Lisbon: IST Press.

VIVAS, E. (2011) A distribuição moderna: a invasão dos supermercados. in E. Vivas \& X. Montagut (coord.) Do Campo para a Mesa. Carcavelos: Sururu Produçóes Culturais.

ZERO DESPERDÍCIO (2017) Zero Desperdício. [online] Available: http://www.zerodesperdicio.pt/ [Accessed: 9 September 2017] 